\title{
Lithospheric mantle beneath NE part of Bohemian Massif and its relation to overlying crust: new insights from Pilchowice xenolith suite, Sudetes, SW Poland
}

\author{
Mateusz Ćwiek $^{1}$ (1) $\cdot$ Magdalena Matusiak-Małek ${ }^{1} \cdot$ Jacek Puziewicz $^{1} \cdot$ Theodoros Ntaflos $^{2}$
}

Received: 13 November 2017 / Accepted: 24 November 2017 / Published online: 11 December 2017

(c) The Author(s) 2017. This article is an open access publication

\begin{abstract}
The Oligocene/Miocene basanite from Pilchowice (Sudetes Mts., SW Poland) carries numerous small xenoliths of mantle peridotite, mostly harzburgite. The Pilchowice xenolith suite is dominated by harzburgites and dunites containing olivine Fo 90.2-91.5 (group A). The peridotites of group B (olivine Fo 88.6-89.4), and C (olivine Fo 83.2-86.5) are subordinate. The peridotites suffered from significant melt extraction (20-30\%) and were subsequently subjected to metasomatism. Three different trace element compositional patterns of group A clinopyroxene occur, which are typical of silicate melt, carbonatite melt and silicate-carbonatite melt metasomatism, whereas groups B and C were affected by silicate melt metasomatism only. The Pilchowice basanite occurs at the contact of Karkonosze-Izera Block and Kaczawa Complex, two major geological units of Sudetes. The Pilchowice xenolith suite documents underlying lithospheric mantle of composition and depletion degree similar to those described in the whole Lower Silesian mantle domain, which forms NE termination of Saxo-Thuringian zone of the European Variscan orogen. The crustal structure of the orogen is, therefore, not mirrored in the mantellic root.
\end{abstract}

Keywords Xenoliths $\cdot$ Mantle $\cdot$ SW Poland $\cdot$ Crust - mantle decoupling

\section{Introduction}

The Variscan orogen of Europe consists of few major tectonostratigraphic units corresponding to individual subduction -collision systems (Mazur et al. 2006; Franke 2014 and references therein). Their mantle roots differ among each other by different seismic anisotropy (Plomerová and Babuška 2010 and references therein). The studies of mantle xenoliths occurring in Cenozoic alkaline volcanic rocks show that the lithologically homogeneous mantle "domains" of lateral size from tens to first hundreds of kilometers occur within each tectonostratigraphic unit of the orogen (e.g., Lenoir et al. 2000; Puziewicz et al. 2015). Thus, the mantle roots of

Electronic supplementary material The online version of this article (https://doi.org/10.1007/s00531-017-1568-4) contains supplementary material, which is available to authorized users.

Mateusz Ćwiek

mateusz.cwiek@uwr.edu.pl

Uniwersytet Wrocławski, Wrocław, Poland

2 Universität Wien, Vienna, Austria major tectonostratigraphic units of the orogen have a mosaic internal structure.

The Lower Silesian mantle domain is overlain by the easternmost part of Saxo-Thuringian Zone and adjoining Central Sudetes accretionary prism (see Mazur et al. 2015 for details of surficial geology). This mantle domain is dominated by depleted harzburgites, overprinted by "Fe-metasomatism" and subsequently by alkaline silicate or silicate-carbonate metasomatism related to Cenozoic alkaline volcanism (Puziewicz et al. 2015). Numerous local variations in rock composition and style of their metasomatic overprint occur within the Lower Silesian mantle domain (e.g., Puziewicz et al. 2011; Matusiak-Małek et al. 2014; Kukuła et al. 2015a). The study of individual xenolith suites contribute to the detailed characteristics of lithospheric mantle, enabling better insight into its geological history. In this paper, we present the case study of mantle xenolith suite from Pilchowice in Lower Silesia which was brought to the surface at ca $23 \mathrm{Ma}$. We discuss the details of mantle evolution recorded in the xenoliths and comment on its significance to the overall characteristics of the Lower Silesian mantle domain of the European Variscan orogen. 


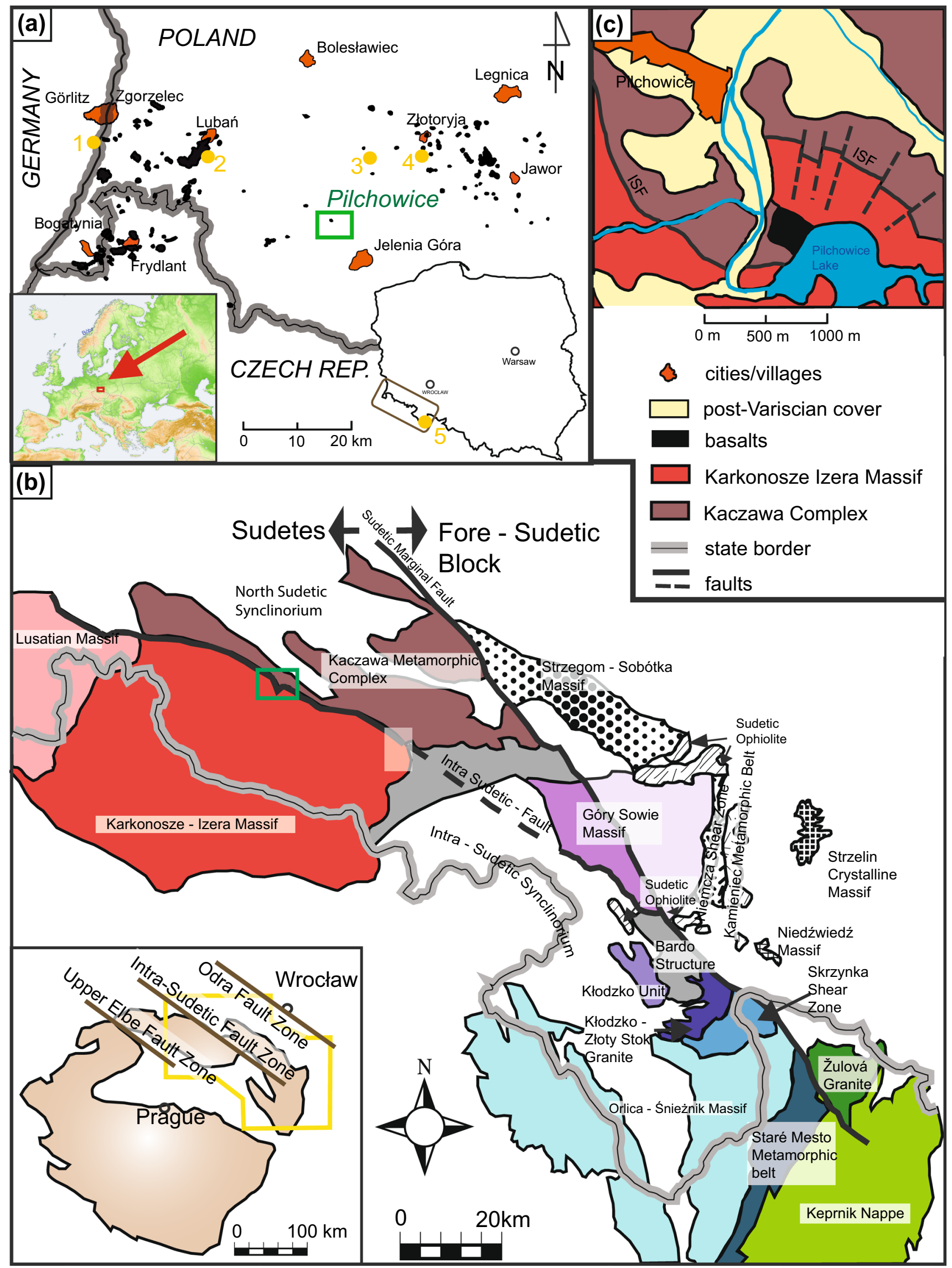


४Fig. 1 a Cenozoic volcanic rocks of SW Poland. Green square indicates location of Pilchowice basanite (Badura and Przybylski 2000, modified); left and right insets show location of the study area in Europe and in Poland, respectively; numbers indicate xenolith localization discussed in text: 1-Steinberg, 2-Księginki, 3-Grodziec, 4-Krzeniów, 5-Lutynia; b geological units forming Sudetes and Fore-Sudetic Block. Lower inset shows sketch of Bohemian Massif with location of Sudetes and main faults (Aleksandrowski et al. 1997, modified); c detailed geological map of Pilchowice area (Szałamacha 1974, modified)

\section{Geological setting}

Cenozoic volcanic rocks from Lower Silesia (SW Poland) belong to the Central European Volcanic Province (CEVP; Wimmenauer 1974). Volcanic activity in CEVP is related to the opening of the Atlantic Ocean and collision of the African and Eurasian Plates in the Late Cretaceous and Paleogene (Wilson and Downes 2006; Lustrino and Wilson 2007), which led to the formation of the European Cenozoic Rift System (ECRIS, Dézes et al. 2004). The Lower Silesian part of CEVP is located at the NE prolongation of the NNE-SSW trending Eger (Ohře) Rift, the easternmost of the ECRIS rifts, situated at the NW part of the Bohemian Massif (Sudetes Mts.), and between the NW-SE trending Odra-Elbe (Labe) faults (Fig. 1).

Over 300 outcrops of Cenozoic alkaline basaltic rocks occur in SW Poland (Birkenmajer et al. 2011). They are concentrated in five volcanic "complexes": Lubań-Frydlant, Złotoryja-Jawor, Niemcza-Strzelin, Lądek Zdrój and Niemodlin (Puziewicz et al. 2015). The lavas have mostly the composition of basanites and nephelinites, and were formed by low-degree melting of garnet and spinel peridotites both in asthenosphere and in lithosphere and by subsequent mixing of these melts (Ladenberger et al. 2006a). Isotopic composition of the melts is intermediate between Depleted MORB Mantle, "High $\mu$ " Mantle and Enriched Mantle (Ladenberger et al. 2006a).

The Pilchowice basanite occurs outside the neighbouring Lubań-Frydlant and Złotoryja-Jawor volcanic complexes (Fig. 1a). It is exposed in an abandoned quarry, $2 \mathrm{~km}$ south from Pilchowice village, ca. $12 \mathrm{~km}$ north from Jelenia Góra (Fig. 1). The basanite forms volcanic plug ( 400 $\mathrm{m}$ in diameter) dated at 23.4 $\pm 1.1 \mathrm{Ma}$ (Birkenmajer et al. 2011). Białowolska (1980) classified it to be a nephelinite, whereas data of Kozłowska-Koch (1987) and ours (Supplementary Material 1) suggest basanite composition. Basanite is porphyric and consist of aphanitic groundmass (fine pyroxene and nepheline plus chloritized glass and scarce rhönite; Ladenberger et al. 2006b) and phenocrysts of euhedral olivine and subhedral clinopyroxene. In clinopyroxene porphyrocrysts, a spongy core is often surrounded by zoned rims. Numerous small (1-3 cm in diameter), mostly strongly weathered, peridotite xenoliths occur in the basanite.
The Pilchowice basanite is located directly on the IntraSudetic Fault (ISF)- a major Variscan NW-SE trending, long-living (Devonian-Carboniferous, Don 1984 or Devonian-Permian; Aleksandrowski et al. 1997) dislocation transecting whole the Sudetes. In the vicinity of Pilchowice the ISF separates Karkonosze-Izera Block (represented by gneisses) from the mica schists of Kaczawa Complex (Fig. 1b). The fault is rather shallow structure (Żelaźniewicz and Franke 1994; Aleksandrowski 1994; Aleksandrowski et al. 2000) and thus could have enhanced the eruption of Pilchowice basanite only in the shallowest part of the crust.

\section{Analytical methods, terminology}

In this study, we present data from 17 xenoliths. Their modal composition has been determined on high-resolution scans of $120 \mu \mathrm{m}$ thick, polished sections in transmitted light with use of JMicroVision free software. Bulk rock major elements of the host basanite were analyzed with the sequential X-ray spectrometer Phillips PW 2400 equipped with a Rh-excitation source. Major elements analyses of minerals have been done in the Department of Lithospheric Research, University of Vienna with use of Cameca SX 100 electron microprobe working under standard conditions (acceleration voltage of $15 \mathrm{kV}$ and sample current $20 \mathrm{nA}$, natural and synthetic minerals as standards, PAP correction procedure applied).

Laser ablation-inductively coupled plasma mass spectrometry (LA-ICPMS) "in situ" trace element analyses of pyroxenes from a majority of xenoliths were conducted in the laboratory of the Institute of Geological Sciences of the Polish Academy of Sciences, Kraków Research Centre, using a Resonetics RESOlution M50 excimer laser (ArF; Müller et al. 2009) coupled with a Thermoelectron XSeriesII ICPMS system. Energy density of $8^{10} \mathrm{~J} \mathrm{~cm}^{-2}$ at a repetition rate of $10 \mathrm{~Hz}$ was applied. Diameter of ablation spot varied from $40 \mu \mathrm{m}$ (clinopyroxene) to $110 \mu \mathrm{m}$ (orthopyroxene); ablation time was $45 \mathrm{~s}$. Sample runs were bracketed by measurements of NIST 612 glass (reference values of Jochum et al. 2011 were adopted) and MPI DING (KL2-G, ML3B-G, GOR128G) glasses as secondary standards (Jochum et al. 2011). Ca content measured by electron microprobe was used as an internal standard. Data processing was performed by Glitter 4.0 (van Achterberg et al. 2001). Some of the LA-ICPMS analyses were conducted at the Institute of Geology, Czech Academy of Sciences, Prague using an Element 2 Thermo Finningan ICP-MS system coupled with UP-213 LA system (New Wave Research). Energy density of $9^{10} \mathrm{~J} \mathrm{~cm}^{-2}$ and laser repetition rate of $20 \mathrm{~Hz}$ was used; ablation time was 25-30 s. Beam diameters were 100 or $55 \mu \mathrm{m}$ (depending on the grain size). In each section, we have analysed ca. 12 spots in 2 crystals of both ortho- and clino-pyroxene. 
Analyses were averaged within xenoliths due to homogeneous content of trace elements.

The $\mathrm{Ti}^{*}$ and $\mathrm{Sr}^{*}$ stand for $\mathrm{Ti}$ and $\mathrm{Sr}$ anomalies, respectively, and were calculated with formulae: $\mathrm{Ti}^{*}=\mathrm{Ti}_{N} /$ $\left(\mathrm{Eu}_{N}+\mathrm{Gd}_{N}\right) / 2$ and $\mathrm{Sr}^{*}=\mathrm{Sr}_{N} /\left(\operatorname{Pr}_{N}+\mathrm{Nd}_{N}\right) / 2($ Gill 2010), respectively; " $N$ " is for primitive mantle normalized values (McDonough and Sun 1995). In the text, we have used the following abbreviations: $\mathrm{Fo}=100 \times \mathrm{Mg} /\left(\mathrm{Mg}+\mathrm{Fe}^{\mathrm{tot}}\right)$, $\mathrm{Mg} \#=\mathrm{Mg} /\left(\mathrm{Mg}+\mathrm{Fe}^{\text {tot }}\right), \mathrm{Cr} \#=\mathrm{Cr} /(\mathrm{Cr}+\mathrm{Al})$ where $\mathrm{Mg}, \mathrm{Fe}^{2+}$, $\mathrm{Fe}^{3+}, \mathrm{Cr}, \mathrm{Al}$ are atomic content of each element per formula unit (apfu). For pyroxenes, we use nomenclature of Morimoto (1989). Minerals abbreviations are: Ol for olivine, Opx for orthopyroxene, Cpx for clinopyroxene, Spl for spinel, Fsp for feldspar, Ne for nepheline, Ccp for chalcopyrite and Pn for pentlandite.

\section{Petrography}

The Pilchowice xenoliths are dark green, angular to oval, their contacts with the host rock are typically sharp but locally $0.5 \mathrm{~mm}$ reaction zones formed of anhedral olivine, orthopyroxene and clinopyroxene occur. The xenoliths have typically composition of harzburgite, but some dunites and wehrlites occur as well (Fig. 2; Table 1). All the xenoliths show protogranular (M3302, M3303, M3304, M3305, M3306, M3308, M3311, M3312a, M3312b, M3313, M3314a, M3314b, M3315) to porphyroclastic (without lineation) texture (M3307; sensu Mercier and Nicolas 1975; Fig. 3). Serpentinization occurs only in marginal parts of some grains. We group grains in three classes, following classification by Matusiak-Małek et al. (2014): I—rockforming, large, subhedral crystals of olivine, ortho- and clinopyroxene and spinel; II-elongated rods or lamellae of spinel, clinopyroxene and rarely orthopyroxene

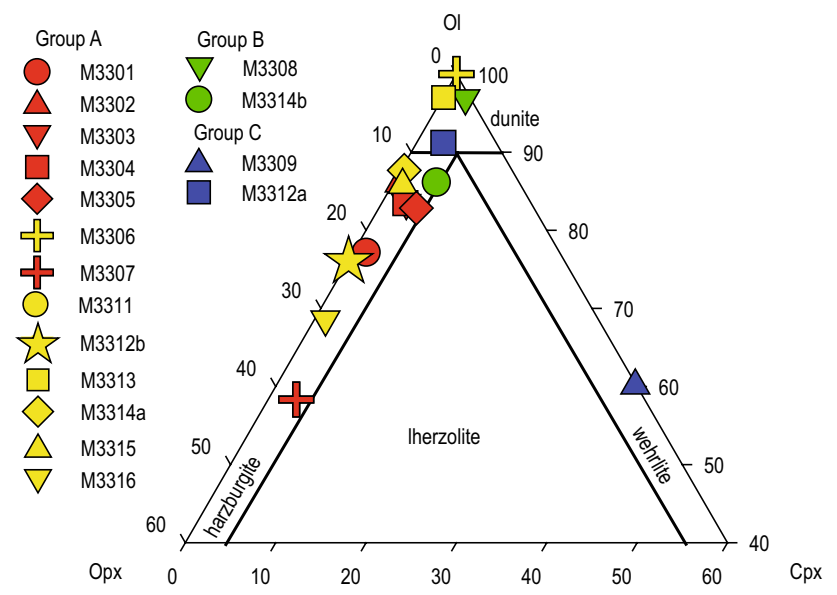

Fig. 2 Mineral composition of xenoliths from Pilchowice in the olivine-orthopyroxene-clinopyroxene classification diagram
Table 1 Modal composition of Pilchowice xenoliths (vol\%)

\begin{tabular}{lrrlll}
\hline & O1 (\%) & Opx $(\%)$ & Cpx $(\%)$ & Sp (\%) & Group \\
\hline M3301 & 74.8 & 20.7 & 1.4 & 3.1 & A \\
M3302 & 85.4 & 13.0 & 0.6 & 0.8 & A \\
M3303 & 81.2 & 13.6 & 2.8 & 2.3 & A \\
M3304 & 82.8 & 13.8 & 2.6 & 0.6 & A \\
M3305 & 81.5 & 12.8 & 4.1 & 1.5 & A \\
M3306 & 100.0 & 0.0 & 0.0 & 0 & A \\
M3307 & 58.1 & 38.4 & 3.1 & 0.3 & A \\
M3311 & 94.2 & 4.9 & 0.5 & 0.2 & A \\
M3312b & 74.8 & 23.4 & 0 & 1.7 & A \\
M3313 & 96.7 & 2.9 & 0.1 & 0.1 & A \\
M3314a & 87.5 & 11.9 & 0.4 & 0.2 & A \\
M3315 & 84.0 & 12.6 & 1 & 2.4 & A \\
M3316 & 65.1 & 28.9 & 1.3 & 4.7 & A \\
M3308 & 96.6 & 0.7 & 2.7 & 0 & B \\
M3314b & 83.9 & 8.9 & 4.6 & 2.5 & B \\
M3312a & 88.9 & 5.7 & 2.9 & 2.4 & C \\
M3309 & 60.4 & 2.8 & 36.8 & 0 & C \\
\hline
\end{tabular}

localized in core parts of ortho- and clinopyroxene; III-fine (50-100 $\mu \mathrm{m})$, euhedral crystals of olivine, clinopyroxene, spinel and feldspar/glass occurring in $\sim 1 \mathrm{~mm}$ "intergranular aggregates" (Fig. 3a).

Olivine I forms 1-5 mm subhedral crystals with deformation lamellae ("kink bands"; Fig. 4a). Orthopyroxene I occurs as subhedral crystals up to $4 \mathrm{~mm}$ long with parallel lamellae of clinopyroxene II and spinel II in cores (Fig. 4b, c). Clinopyroxene I is anhedral and typically up to $2 \mathrm{~mm}$ long and forms clusters with spinel I (Figs. 3b, 4d). Some crystals of clinopyroxene are partly or overall spongy (Fig. 4e). Pores in the spongy clinopyroxene are filled by glass, feldspar and spinel. Relatively large grains of spinel, interpreted by us to be spinel I, occur only in the intergranular aggregates. Those spinel I crystals are mainly isometric, subhedral and up to $2 \mathrm{~mm}$ long. Large spinel crystals with broad spongy rims occur in harzburgite M3315 and millimetric-size spinel symplectite occurs in the intergranular aggregate in harzburgite M3316.

The intergranular aggregates consisting of olivine III, clinopyroxene III, spinel III and glass occur abundantly in most of the xenoliths (Figs. 3a, 4f, g). Only in xenoliths M3312 and M3309 the aggregates are limited to fine grained mixture of olivine III, clinopyroxene III and glass forming $<50 \mu \mathrm{m}$ thick rims around orthopyroxene I (Fig. 4h). Olivine III and clinopyroxene III are subhedral and form $0.1 \mathrm{~mm}$ long crystals. Massive, oval cores surrounded by angular rim occur in some of the clinopyroxene III crystals. Spinel III forms subhedral, angular, $150 \mu \mathrm{m}$ crystals, often poikilitically enclosed in olivine III and clinopyroxene III. Small patches of locally devitrified glass occur 

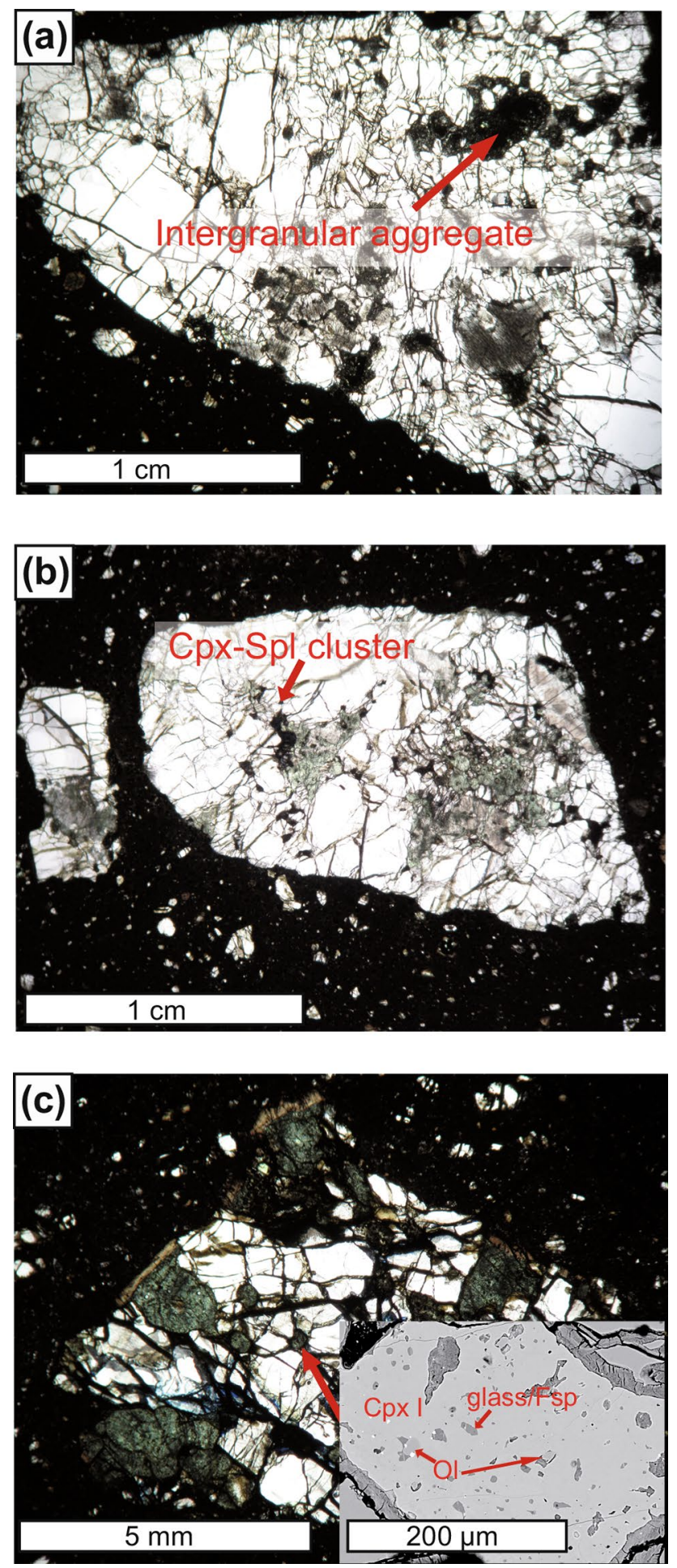

Fig. 3 Xenolith textures in plane polarized light. a Harzburgite M3314a, porphyroclastic texture grading towards the equigranular one in the surrounding of the intergranular aggregate; $\mathbf{b}$ harzburgite M3314b, protogranular texture with clinopyroxene - spinel cluster; c wehrlite M3309, dusty appearance of clinopyroxene results from its spongy texture (inset shows texture of the clinopyroxene in BSE image) among crystalline phases forming intergranular aggregates (Fig. 4g). In some of the aggregates, larger $(400 \mu \mathrm{m})$ crystals of spinel III formed of massive core and spongy rim occur.

Harzburgite M3303 contains angular (Fig. 5a) pool dominated by glass. Two types of glass occur in the pool: "dark" (in BSE image) surrounding euhedral, rhomboidal crystals of clinopyroxene up to $50 \mu \mathrm{m}$ long and $10 \mu \mathrm{m}$ thick) and "light", enclosing numerous acicular $(<1 \mu \mathrm{m}$ thick) or bigger, euhedral crystals of clinopyroxene as well as barrelshaped crystals of apatite and scarce sulphides-pentlandite and chalcopyrite (Fig. 5b). Close to the euhedral crystals of clinopyroxene, the "light" glass is always free of acicular clinopyroxene and other crystalline phases (Fig. 5b). The "dark" glass is scarcely clear: if it occurs as blebs in the "light" glass, it encloses roundish, very-fine lighter phases (Fig. 5b). Angular aggregate formed of nepheline and glass with subordinate crystals of chalcopyrite and pentlandite occurs in xenolith M3311 (Fig. 5c).

\section{Chemical composition of minerals}

Based on the forsterite content in olivine I, we have divided xenoliths into three groups. Group A olivine I is characterized by forsterite content varying from 90.2 to $91.5 \%$, groups $\mathrm{B}$ and $\mathrm{C}$ by olivine I containing 88.6-89.4 and 83.2-86.5\% of forsterite, respectively (Fig. 6; Table 2). Olivine grains located at xenolith/basanite contact are enriched in $\mathrm{Ca}$ (up to ca $1200 \mathrm{ppm}$ ) and impoverished in Fo (e.g. 84.20\% in A xenoliths) and are not discussed in the following.

\section{Group A}

Crystals of olivine I in group A xenoliths are chemically homogeneous. $\mathrm{NiO}$ content is $0.33-0.45 \mathrm{wt} \%$ (Fig. 6; Table 2) and $\mathrm{CaO}$ content reaches $0.11 \mathrm{wt} \%$ (780 ppm Ca).

Orthopyroxene I has composition of $\mathrm{Al}-\mathrm{Cr}$ enstatite. Magnesium number varies from 0.91 to 0.92 and is negatively correlated with Al content (0.02-0.15 apfu; Fig. 7a; Table 3). Composition of clear rims and lamellae-bearing cores is either similar or the lamellae-bearing cores is enriched in $\mathrm{Al}$ relative to clear rims. Calcium content is 0.01-0.05 apfu. Rare earths elements (REE) patterns of group A orthopyroxene are either U-shaped with the inflection point on Eu or Gd or Light REE (LREE)depleted (Fig. 7c, d). The $(\mathrm{La} / \mathrm{Lu})_{N}$ is $0.04-0.92$ in the LREE-depleted orthopyroxene and 0.24 in the U-shaped orthopyroxene. Orthopyroxene I is typically characterized by $\mathrm{Sr}, \mathrm{Zr}-\mathrm{Hf}$ and $\mathrm{Ti}$ negative anomalies (Fig. 7e, f). Orthopyroxene in xenolith M3315 is very depleted in almost all the trace elements, but the $\mathrm{Zr}$, Hf and $\mathrm{Ti}$ contents are similar to that in other group A orthopyroxene 

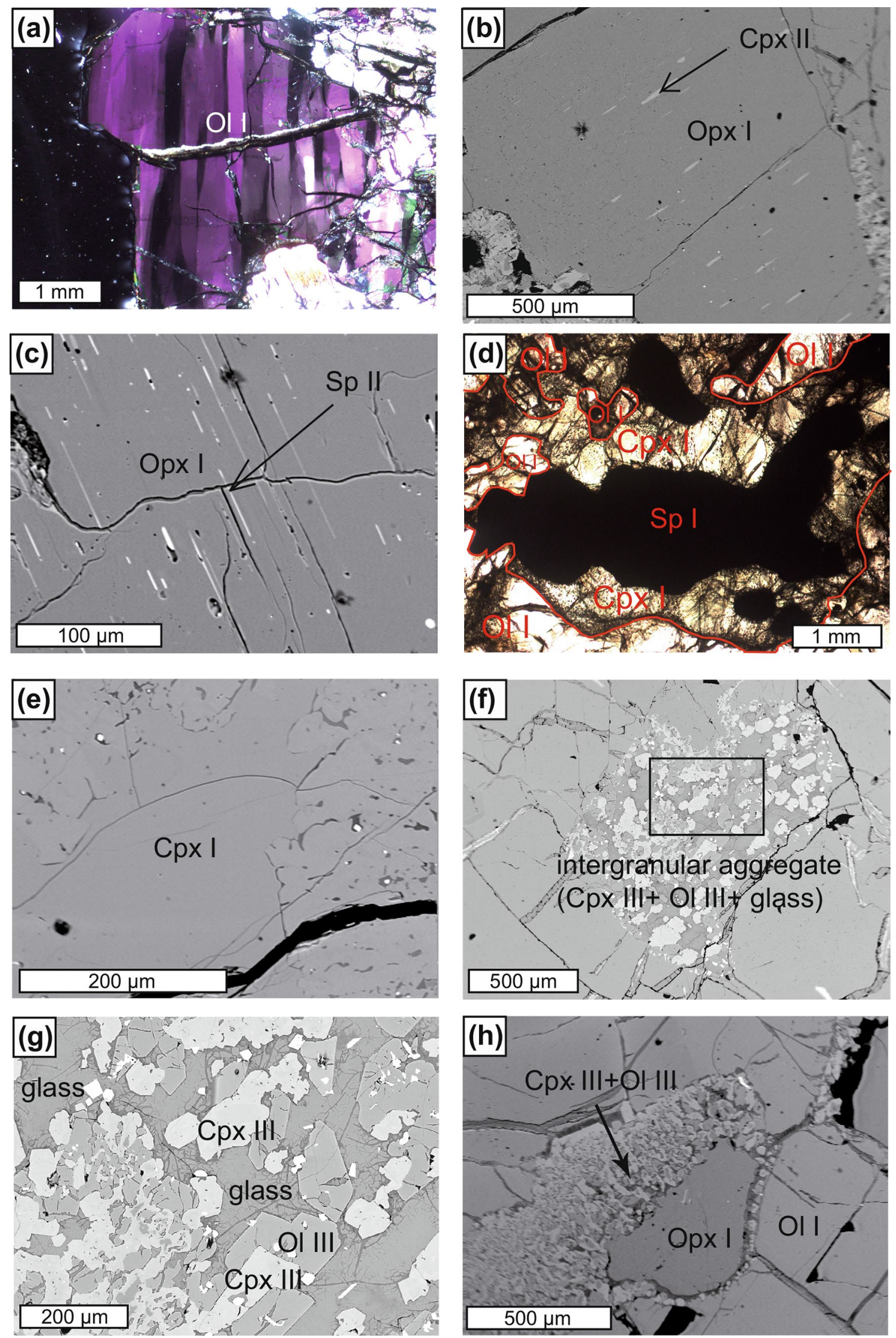
४Fig. 4 Textural features of Pilchowice xenoliths. a Kink bands in olivine I crystal (xenolith M3314a, crossed polars); b Clinopyroxene II lamellae in orthopyroxene I (xenolith M3314b, BSE image); c Spinel II lamellae in orthopyroxene I (xenolith M3314a, BSE image); d Spinel I - clinopyroxene I clusters (xenolith M3303, plane polarized light; red lines delineate clinopyroxene I and olivine I); e rims of spongy clinopyroxene enveloping massive clinopyroxene I (xenolith M3307, BSE image); $\mathbf{f}$ general image of intergranular aggregate (xenolith M3311, BSE image), square indicates area enlarged in figure (g); $\mathbf{g}$ details of texture of intergranular aggregate (xenolith M3311, BSE image); h clinopyroxene III with remnants of clinopyroxene I in core (xenolith M3314a, BSE image). Abbreviations of the mineral names are explained in "Analytical methods, terminology, geothermometry" section

resulting in positive anomalies (Fig. 7e; Table 4). We suggest that LREE-enriched analyses are contaminated by intergrowths of clinopyroxene II.

Clinopyroxene I has composition of $\mathrm{Cr}$ or $\mathrm{Cr}, \mathrm{Ti}, \mathrm{Al}$ diopside. The $\mathrm{Mg \#}$ varies widely $(0.90-0.95)$ as well as $\mathrm{Al}(0.04-0.17 \mathrm{apfu})$ and $\mathrm{Ca}(0.74-0.96 \mathrm{apfu})$ contents (Fig. 8a, b; Table 5). Titanium content is $0.01-0.09$ apfu and is negatively correlated with $\mathrm{Cr}(0.00-0.07 \mathrm{apfu}$, not shown).

Three types of REE patterns occur in group A Pilchowice clinopyroxene I and on this basis we divided the xenoliths into subgroups A1, A2 and A3. Subgroup A1 (xenolith M3315) clinopyroxene I is characterized by HREE and MREE contents at primitive mantle level and elevated LREE contents $\left[(\mathrm{La} / \mathrm{Lu})_{N}=8.75\right.$; Fig. $8 \mathrm{c}$ and Table 6]. A multi-trace elements diagram shows slight Hf and $\mathrm{Ti}\left(\mathrm{Ti} / \mathrm{Ti}^{*}=0.5\right)$ negative anomalies and $\mathrm{U}$ and $\mathrm{Sr}(\mathrm{Sr} /$ $\mathrm{Sr}^{*}=1.3$ ) positive anomalies (Fig. 8e; Table 6). Subgroup A2 (xenoliths M3301, M3302, M3303, M3304, M3307) clinopyroxene is constantly LREE enriched with the inflection point in Nd [Fig. 8e; $\left.(\mathrm{La} / \mathrm{Lu})_{N}=3.43-9.97\right]$. Prominent Nb, Ta, Zr, Hf, Ti $\left(\mathrm{Ti} / \mathrm{Ti}^{*}=0.00-0.08\right)$ negative anomalies occur in the multi-trace element diagram as well as small negative $\mathrm{Sr}$ anomaly $\left(\mathrm{Sr} / \mathrm{Sr}^{*}=0.83-0.94\right.$; Fig. 8f; Table 6). Subgroup A3 (xenolith M3314b) is characterized by the REE pattern showing a constant linear enrichment in LREE (Fig. 8c). The (La/Lu) $)_{N}$ is 19.99 . The TE diagram shows $\mathrm{Nb}, \mathrm{Ta}, \mathrm{Zr}, \mathrm{Hf}, \mathrm{Ti}\left(\mathrm{Ti} / \mathrm{Ti}^{*}=0.01\right)$ negative anomalies (Fig. 8e; Table 6) while Th-U contents are $\sim 70$ times higher than in primitive mantle.

Spinel I, occurring in the intergranular aggregates, is poor in $\mathrm{TiO}_{2}(0.04-0.20 \mathrm{wt} \%)$, with high $\mathrm{Cr} \#(0.46-0.82)$ and relatively low $\mathrm{Mg} \#(0.61-0.63)$. Its composition is varying between xenoliths, but is usually homogenous within a single sample (Fig. 9; Table 7). The only heterogeneous spinel occurs in harzburgite M3315, where cores have $\mathrm{Cr} \#=0.31-0.35, \mathrm{Mg} \# 0.67-0.70$ and $\mathrm{TiO}_{2}$ content is 0.07-0.10 wt\% (Fig. 9; Table 7).

\section{Group B}

Olivine occurring in group B xenoliths contains 88.6-89.4\% of forsterite. Its $\mathrm{NiO}$ and $\mathrm{Ca}$ contents $(0.35-0.39 \mathrm{wt} \%$ and 120-740 ppm, respectively) are similar to those of the group A olivine (Fig. 6; Table 2).

Orthopyroxene I (Mg\# 0.90-0.91) is Cr enstatite. Chemical composition of lamellae-bearing cores and clear rims is the same. Al content ranges from 0.05 to 0.09 apfu and that of $\mathrm{Ca}$ is $0.02-0.03 \mathrm{apfu}$ (Fig. 7a, b; Table 3). The orthopyroxenes' REE pattern shows a constant decrease from HREE to LREE $\left[(\mathrm{La} / \mathrm{Lu})_{N}=0.12 ;\right.$ Fig. $\left.7 \mathrm{c}\right]$ and is characterized by $\mathrm{Sr}\left(\mathrm{Sr} / \mathrm{Sr}^{*}=0.08\right)$ and $\mathrm{U}$, Th and $\mathrm{Ti}\left(\mathrm{Ti} / \mathrm{Ti}^{*}=1.45\right)$ positive anomalies (Fig. 7d; Table 4).

Clinopyroxene I (Mg\# 0.90-0.91, Fig. 8a) has composition of $\mathrm{Al}-\mathrm{Cr}$ or $\mathrm{Cr}$ diopside. It contains $0.08-0.15$ atoms of $\mathrm{Al}$ pfu (Fig. 8a). Calcium content varies at the scale of single grains [0.75-0.92 atoms of Ca pfu (Fig. 8b)]. No clear correlation between $\mathrm{Cr}, \mathrm{Mg \#}$ and $\mathrm{Al}$ like in group $\mathrm{A}$ occurs. The REE content of group B clinopyroxene is similar to that in A2 subgroup $\left[(\mathrm{La} / \mathrm{Lu})_{N}=5.55\right]$, but an inflection point is less prominent (Fig. 8c). A multi-trace element diagram shows deep $\mathrm{Ta}, \mathrm{Nb}, \mathrm{Zr}$, Hf and $\mathrm{Ti}\left(\mathrm{Ti} / \mathrm{Ti}^{*}=0.31\right)$ anomalies (Fig. 8e; Table 6) and slight $\mathrm{Sr}$ negative anomaly $(\mathrm{Sr} /$ $\left.\mathrm{Sr}^{*}=0.16\right)$. Clinopyroxene II has composition similar to that of clinopyroxene $\mathrm{I}(\mathrm{Mg} \#=0.90-0.91, \mathrm{Al}=0.13-0.14$ apfu, $\mathrm{Ca}=0.82-0.83 \mathrm{apfu}$ ). The group $\mathrm{B}$ spinel is scarce and forms minute crystals.

\section{Group C}

Olivine I contains 83.2-86.5\% of forsterite (Fig. 6; Table 2). The $\mathrm{NiO}$ content is $0.22-0.41 \mathrm{wt} \%$, whereas the $\mathrm{CaO}$ content ranges between 0.06 and $0.18 \mathrm{wt} \%$ (400-1280 ppm). Contents of $\mathrm{CaO}$ on the edges of crystals are higher than those in the core parts.

Orthopyroxene I (Mg\# 0.86-0.88) has composition of Cr enstatite (Fig. 7a, b; Table 3). The $\mathrm{Al}$ and $\mathrm{Ca}$ contents are 0.09-0.12 and 0.03-0.04 apfu, respectively. Orthopyroxene I is LREE-depleted [(La/Lu $\left.)_{N}=0.04\right]$; its multi-trace element diagram shows negative anomalies in $\mathrm{Sr}\left(\mathrm{Sr} / \mathrm{Sr}^{*}=0.07\right)$, $\mathrm{Zr}-\mathrm{HfandTi}\left(\mathrm{Ti} / \mathrm{Ti}^{*}=0.12\right.$ ) and elevated U content (Fig. 7d; Table 4). Orthopyroxene II is chemically similar to orthopyroxene $\mathrm{I}(\mathrm{Mg} \#=0.88, \mathrm{Al}=0.12 \mathrm{apfu}, \mathrm{Ca}=0.04 \mathrm{apfu})$.

The chemical composition of clinopyroxene I forming group $\mathrm{C}$ varies between xenoliths. Mg\# in xenolith M3312a is $0.86-0.88$, while in xenolith M3309 it is $0.88-0.90$ (Fig. 8a, b). The $\mathrm{Al}$ content is $0.17-0.20 \mathrm{apfu}$ in xenolith M3312a and 0.08-0.13 apfu in xenolith M3309. Ti content varies within the range of 0.01-0.09 apfu and is inversely correlated with the $\mathrm{Cr}$ content $(0.02-0.06 \mathrm{apfu})$.Clinopyroxene from both group $\mathrm{C}$ xenoliths is LREE-enriched with inflection at the most incompatible elements (Fig. 8c). 
Fig. 5 Textures of glassy pools. a General appearance of the pool (xenolith M3303, reflected light); b lathy crystals of clinopyroxene ("fassaite") embedded in glassy matrix (xenolith M3303, BSE image); c Glassy pool in xenolith M3311 (BSE image). Abbreviations of the mineral names are explained in "Analytical methods, terminology, geothermometry" section
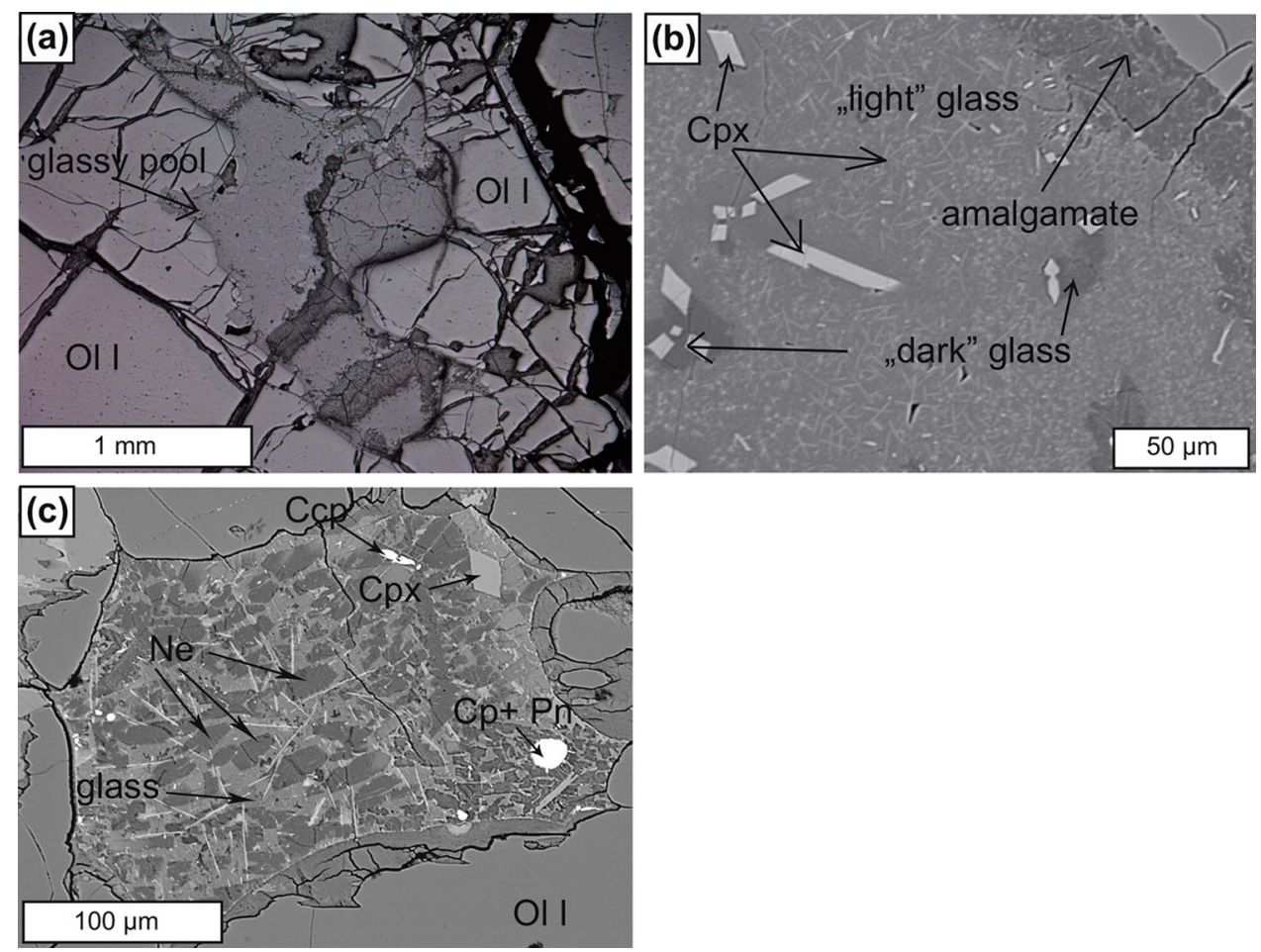
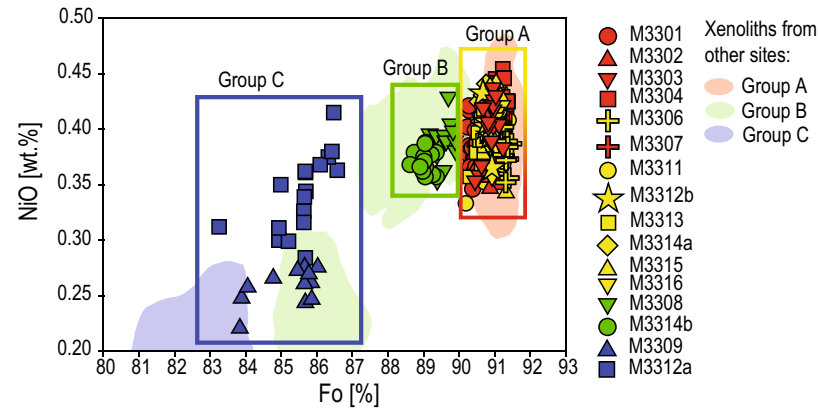

Fig. $6 \mathrm{NiO}$ vs Fo contents in olivine I forming the Pilchowice xenoliths with marked division into groups (see text)

The $(\mathrm{La} / \mathrm{Lu})_{N}$ ratio is 5.05 in xenolith M3312a and 2.91 in xenolith M3309. Clinopyroxene from both xenoliths shows negative $\mathrm{Nb}, \mathrm{Zr}, \mathrm{Hf}, \mathrm{Sr}\left(\mathrm{Sr} / \mathrm{Sr}^{*}=0.17-0.58\right)$ and $\mathrm{Ti}(\mathrm{Ti} /$ $\mathrm{Ti}^{*}=0.10-0.11$ ) anomalies (Fig. 8e; Table 6).

The group $\mathrm{C}$ spinel has composition similar to that in other groups $(\mathrm{Mg} \#=0.57-0.60, \mathrm{Cr} \#=0.38-0.42)$, despite the higher $\mathrm{TiO}_{2}$ content (1.64-1.81 wt\%, Table 7).

\section{Chemical composition of phases forming intergranular aggregates}

The Fo (87.5-91.7\%) and $\mathrm{NiO}(0.32-0.41 \mathrm{wt} \%)$ contents in olivine III are similar to those of olivine I in a given xenolith, but the mineral is significantly richer in $\mathrm{Ca}(840-2650 \mathrm{ppm}$;
Table 2). Only in group C xenoliths olivine III has higher

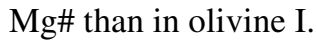

Clinopyroxene III is $\mathrm{Cr}-\mathrm{Al}-\mathrm{Ti}$ augite or diopside. Locally, composition of its cores mimics that of clinopyroxene I in the same xenolith. Mg-number of clinopyroxene III ranges from 0.85 (in group C)to 0.92 (in group A; Fig. 8a; Table 5). The $\mathrm{Al}$ contents of clinopyroxene III are relatively high $(\mathrm{Al}=0.05-0.25 \mathrm{apfu}$; Fig. 8a), except that forming rims around orthopyroxene I( $0.01-0.02$ atoms of Al pfu; Table 5). The $\mathrm{Cr}$ number of spinel III varies from 0.54 to 0.73 , while $\mathrm{Mg} \#$ is rather constant $(0.50-0.56)$. Content of $\mathrm{TiO}_{2}$ is similar to that of spinel I and varies from 0.06 to $0.65 \mathrm{wt} \%$ (Fig. 9; Table 7). The glasses contain 55.61-60.29 wt\% of $\mathrm{SiO}_{2}$, and the totals of $\mathrm{Na}_{2} \mathrm{O}$ and $\mathrm{K}_{2} \mathrm{O}$ are 6.56-14.59 wt\%, classifying most of the glasses as phonolites, but more and less evolved compositions occur as well (Fig. 10).

Clinopyroxene III occurring in "glassy patch" in xenolith M3303 has the composition of subsilicic Al-Fe-Ti diopside of $\mathrm{Mg} \# 0.79-0.81$ (Table 5), while coexisting apatite is fluoroapatite $(F=3.25 \mathrm{wt} \%$; Table 8). The glassy patch from xenolith M3311 consist of nepheline $(\mathrm{Na}=0.97-1.03 \mathrm{apfu})$ chloritized glass, $(\mathrm{FeO}=15.50$ wt $\%, \mathrm{Na}_{2} \mathrm{O}+\mathrm{K}_{2} \mathrm{O}=0.02-0.30 \mathrm{wt} \%$ ), euhedral clinopyroxene $(\mathrm{Mg} \#=0.81-0.84)$ and chalcopyrite-pentlandite bleb. The glass has composition of foidite, but with two chemical varieties: the clear "dark" glass surrounding euhedral clinopyroxene is rich in $\mathrm{Na}_{2} \mathrm{O}=13.95-14.05 \mathrm{wt} \%$ and poor in $\mathrm{K}_{2} \mathrm{O}$ (0.53-0.85 wt\%), whereas "light" glass has the lower $\mathrm{Na}_{2} \mathrm{O}$ 


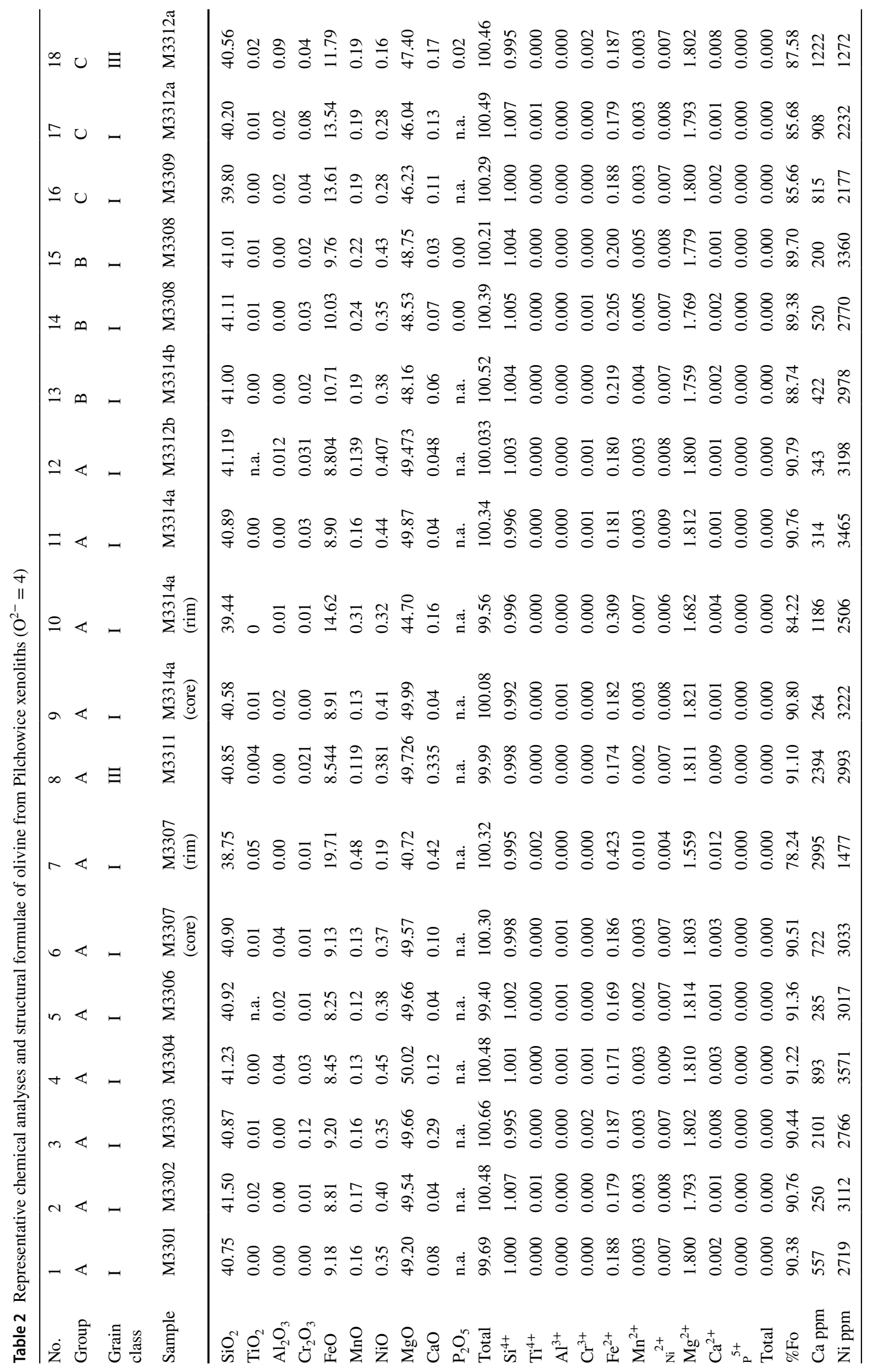



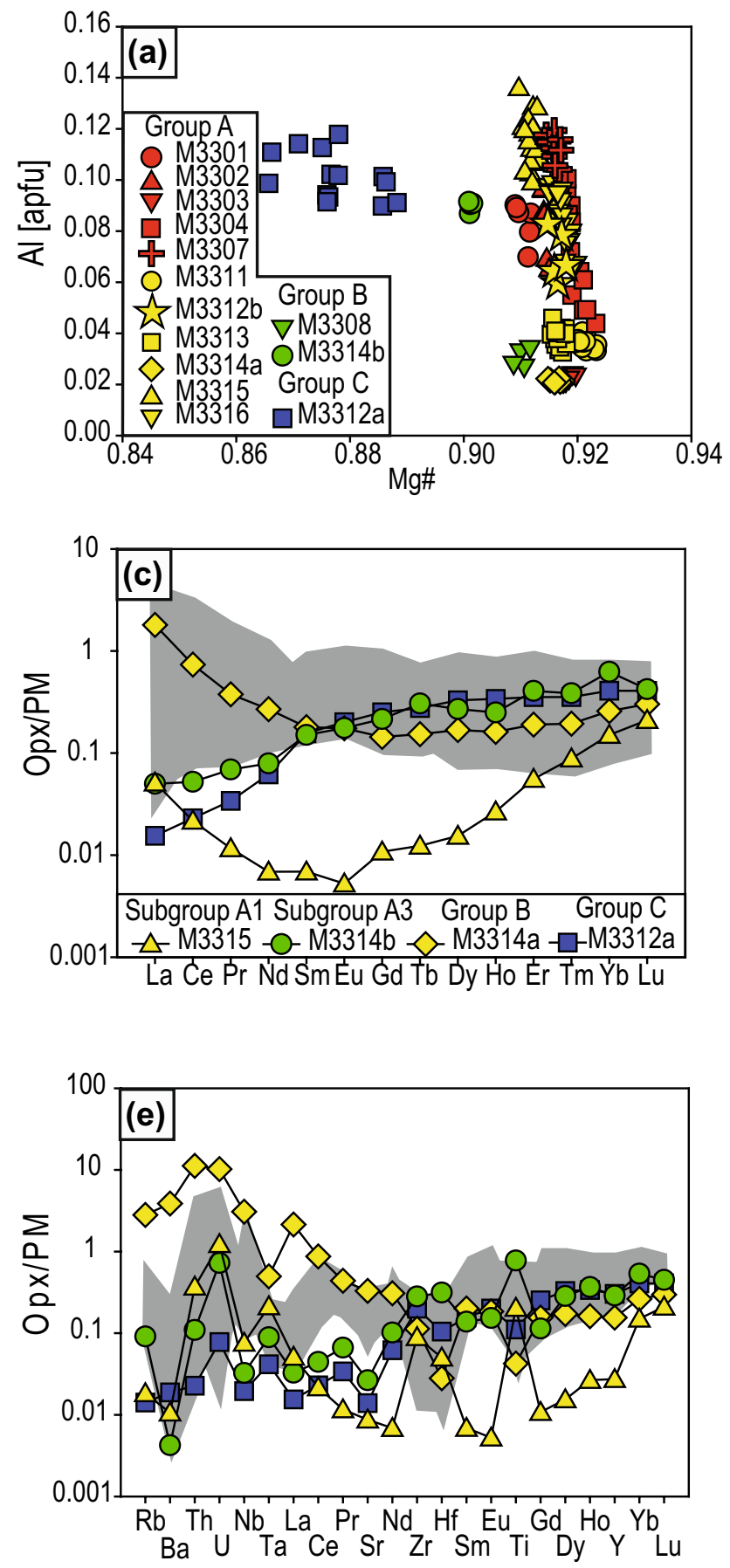

Fig. 7 Chemical composition of orthopyroxene I. a Al content vs Mg\#; b Ca content vs Mg\#; primitive mantle-normalized (McDonough and Sun 1995) REE (c, d) and multi-trace elements patterns (e,

content (4.17-7.51 wt\%), but higher $\mathrm{K}_{2} \mathrm{O}$ content (7.40-8.80 wt $\%$; Table 8).
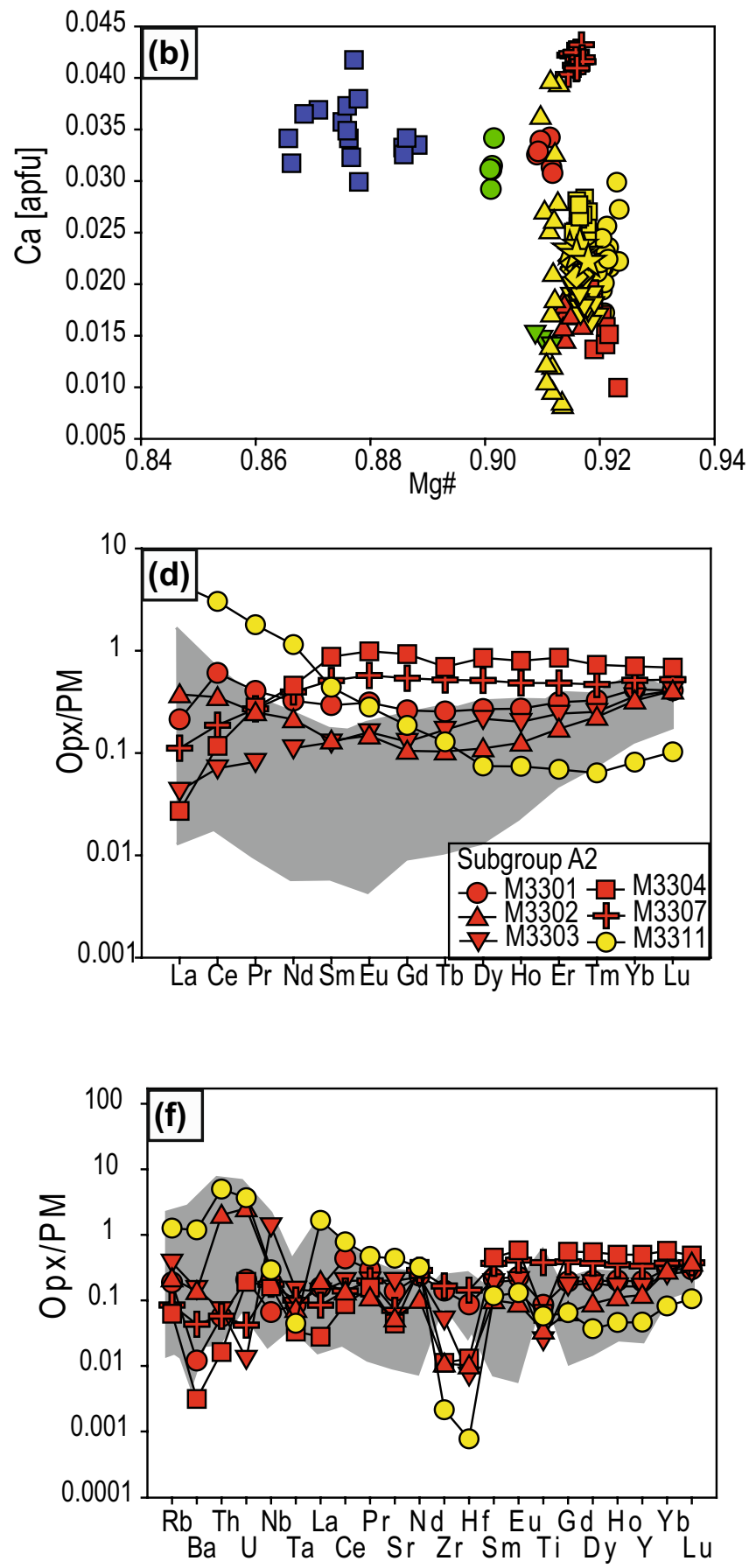

f) in orthopyroxene I. Grey fields in c, e show range of orthopyroxene composition in $\mathbf{d}, \mathbf{f}$ and reversed. Division into subgroups is based on clinopyroxene composition

\section{Discussion}

\section{Evolution of the Pilchowice peridotites}

Peridotitic xenoliths exhumed to the surface by alkaline lavas represent rocks forming Earth's lithospheric mantle 


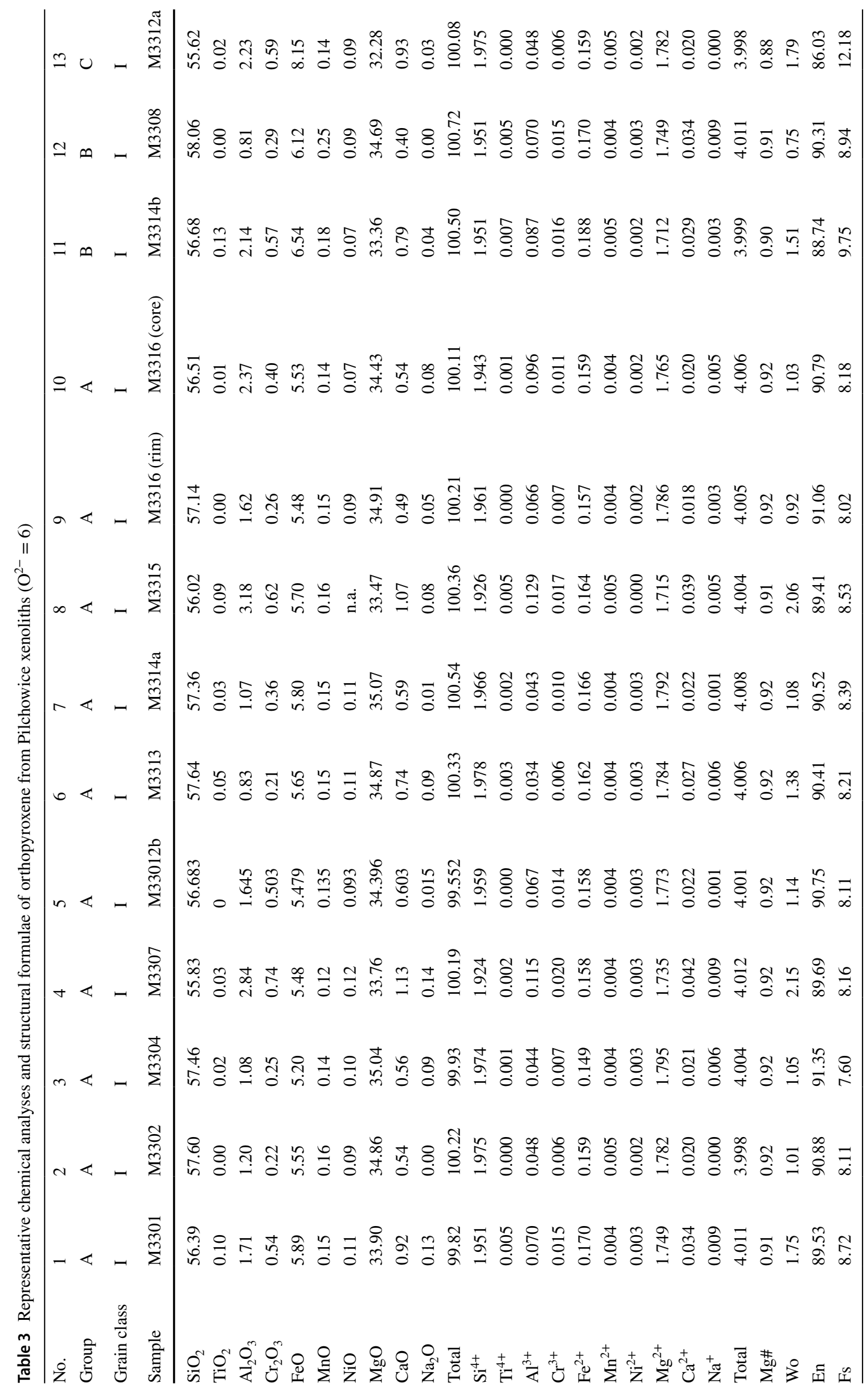


Table 4 Averaged content of trace elements in orthopyroxene from Pilchowice xenoliths (in ppm)

\begin{tabular}{|c|c|c|c|c|c|c|c|c|c|}
\hline No. & 1 & 2 & 3 & 4 & 5 & 6 & 7 & 8 & 9 \\
\hline Group & $\mathrm{A}$ & $\mathrm{A}$ & $\mathrm{A}$ & $\mathrm{A}$ & $\mathrm{A}$ & $\mathrm{A}$ & $\mathrm{A}$ & $\mathrm{B}$ & $\mathrm{C}$ \\
\hline Grain class & I & I & I & I & I & I & I & I & I \\
\hline Sample & M3301 & M3302 & M3303 & M3304 & M3307 & M3314a & M3315 & M3314b & M3312a \\
\hline Number of analyses & 3 & 4 & 3 & 2 & 7 & 6 & 8 & 2 & 6 \\
\hline $\mathrm{Rb}$ & 0.26 & 0.29 & 0.53 & n.a. & 0.11 & 2.81 & 0.02 & 0.09 & 0.01 \\
\hline $\mathrm{Ba}$ & 0.02 & 0.19 & 0.20 & 0.00 & 0.06 & 3.87 & 0.01 & 0.00 & 0.02 \\
\hline Th & 0.07 & 2.98 & 0.09 & n.a. & 0.08 & 11.20 & 0.37 & 0.11 & 0.02 \\
\hline $\mathrm{U}$ & 0.28 & 3.79 & 0.02 & 0.36 & 0.05 & 10.24 & 1.23 & 0.72 & 0.08 \\
\hline $\mathrm{Nb}$ & 0.09 & 0.37 & 1.98 & 0.22 & 0.24 & 3.08 & 0.08 & 0.03 & 0.02 \\
\hline $\mathrm{Ta}$ & 0.11 & 0.10 & 0.20 & 0.04 & 0.13 & 0.50 & 0.21 & 0.09 & 0.04 \\
\hline $\mathrm{La}$ & 0.21 & 0.27 & 0.18 & 0.04 & 0.11 & 2.15 & 0.05 & 0.03 & 0.02 \\
\hline $\mathrm{Ce}$ & 0.61 & 0.18 & 0.27 & 0.12 & 0.19 & 0.87 & 0.02 & 0.04 & 0.02 \\
\hline $\mathrm{Pb}$ & 0.07 & 0.17 & 0.15 & 0.03 & 0.16 & 2.98 & 0.04 & 0.03 & 0.01 \\
\hline $\operatorname{Pr}$ & 0.40 & 0.15 & 0.27 & 0.21 & 0.27 & 0.44 & 0.01 & 0.07 & 0.03 \\
\hline $\mathrm{Sr}$ & 0.19 & 0.07 & 0.27 & 0.06 & 0.09 & 0.33 & 0.01 & 0.03 & 0.01 \\
\hline $\mathrm{Nd}$ & 0.33 & 0.13 & 0.31 & 0.42 & 0.40 & 0.31 & 0.01 & 0.10 & 0.06 \\
\hline $\mathrm{Zr}$ & 0.19 & 0.01 & 0.07 & 0.01 & 0.22 & 0.11 & 0.09 & 0.28 & 0.20 \\
\hline $\mathrm{Hf}$ & 0.11 & 0.01 & 0.01 & 0.02 & 0.19 & 0.03 & 0.05 & 0.32 & 0.10 \\
\hline $\mathrm{Sm}$ & 0.29 & 0.13 & 0.26 & 0.63 & 0.51 & 0.20 & 0.01 & 0.14 & 0.16 \\
\hline $\mathrm{Eu}$ & 0.31 & 0.12 & 0.28 & 0.82 & 0.57 & 0.18 & 0.01 & 0.15 & 0.20 \\
\hline $\mathrm{Ti}$ & 0.11 & 0.04 & 0.03 & 0.08 & 0.53 & 0.04 & 0.20 & 0.78 & 0.11 \\
\hline $\mathrm{Gd}$ & 0.26 & 0.09 & 0.23 & 0.78 & 0.54 & 0.16 & 0.01 & 0.11 & 0.25 \\
\hline Dy & 0.27 & 0.12 & 0.25 & 0.77 & 0.51 & 0.17 & 0.02 & 0.29 & 0.33 \\
\hline Ho & 0.27 & 0.15 & 0.22 & 0.70 & 0.49 & 0.16 & 0.03 & 0.37 & 0.34 \\
\hline $\mathrm{Yb}$ & 0.42 & 0.39 & 0.35 & 0.81 & 0.51 & 0.26 & 0.15 & 0.54 & 0.41 \\
\hline $\mathrm{Y}$ & 0.27 & 0.16 & 0.22 & 0.70 & 0.46 & 0.16 & 0.03 & 0.03 & 0.30 \\
\hline $\mathrm{Lu}$ & 0.41 & 0.52 & 0.38 & 0.68 & 0.52 & 0.30 & 0.21 & 0.21 & 0.41 \\
\hline$(\mathrm{La} / \mathrm{Lu})_{N}$ & 0.52 & 0.51 & 0.48 & 0.05 & 0.21 & 7.23 & 0.24 & 0.16 & 0.04 \\
\hline $\mathrm{Ti}^{*}$ & 0.39 & 0.44 & 0.12 & 0.10 & 0.94 & 0.25 & 25.50 & 5.81 & 0.49 \\
\hline $\mathrm{Sr}^{*}$ & 0.51 & 0.48 & 0.93 & 0.18 & 0.28 & 0.88 & 0.95 & 0.32 & 0.29 \\
\hline
\end{tabular}

(e.g. Downes 2001). A mantle origin of group A peridotites from Pilchowice is suggested by the high modal content of olivine (group I by Frey and Prinz 1978) and its high Fo content (90.2-91.5\%; Pearson et al. 2003; Fig. 6). The Pilchowice xenoliths plot in the Olivine-Spinel Mantle Array field by Arai (1994) and in the Phanerozoic mantle field by Griffin et al. (1999). Group B xenoliths shows the lower Fo content (88.62-89.39\%) in olivine I. In both groups, the high Fo content is followed by high Mg\# values in coexisting orthopyroxene (0.91-0.92 in group A and $0.90-0.91$ in group B). Olivine is abundant in group $\mathrm{C}$ xenoliths, but it is less magnesian $(\mathrm{Fo}=83.25-86.47 \%)$ relative to that of groups $\mathrm{A}$ and $\mathrm{B}$. The spinel in group $\mathrm{C}$ is relatively rich in $\mathrm{TiO}_{2}(1.64-1.81 \mathrm{wt} \%)$.

Peridotites chemically classified as groups A, B and $C$ have been recognized in most mantle xenolith suites at the northern margin of the Bohemian Massif (Fig. 6). Typically, group $\mathrm{C}$ xenoliths are of cumulative origin
(Matusiak-Małek et al. 2017a, b; Kukuła et al. 2015b; Puziewicz et al. 2011).

The Pilchowice peridotites are mostly harzburgites and dunites. Such a clinopyroxene-poor lithology suggests the rocks to be restites after extraction of basaltic melt. Estimates of partial melting degree can be done based on the $\mathrm{MgO}-\mathrm{Al}_{2} \mathrm{O}_{3}$ relationships in orthopyroxene I (Upton et al. 2011; Fig. 11), which suggest that group A and B xenoliths were subjected to c. $20-30 \%$ of melt extraction. The orthopyroxene in group $\mathrm{C}$ harzburgite seems not to be shaped by partial melting.

The modal content of orthopyroxene in variable models of primitive mantle varies from $\sim 23$ to $\sim 30 \mathrm{vol} \%$. (Walter 2003 and references therein) and in general is correlated negative with degree of partial melting (Walter 2003). The modal content of orthopyroxene in depleted rocks should be lower, which is the case in most of the Pilchowice xenoliths (Table 1). However, harzburgites M3307 and M3316 

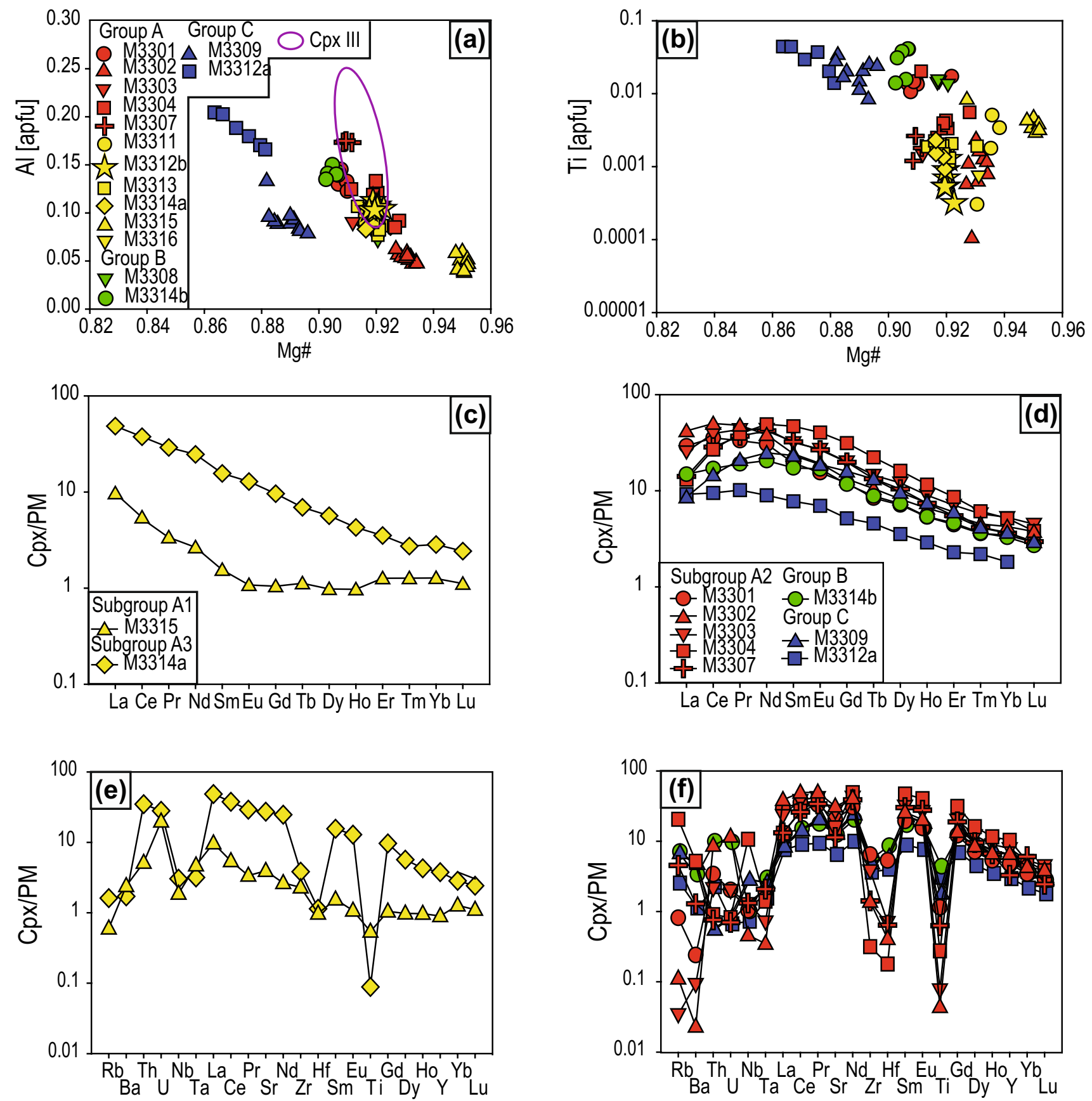

Fig. 8 Chemical composition of clinopyroxene I. a Al content vs Mg\#; b Ca content vs Mg\#; c, d Primitive mantle-normalized (McDonough and Sun 1995) REE patterns; e, f multi-trace elements patterns. Grey fields in $\mathbf{c}, \mathbf{e}$ show range of clinopyroxene composition in $\mathbf{d}, \mathbf{f}$ and reversed

(both group A) have elevated content of the mineral (38 and $29 \mathrm{vol} \%$, respectively). As such these phenomena cannot be easily explained by melting processes, some orthopyroxene I must have been added to the rocks and possibly is a metasomatic phase.

Approximately $25 \%$ of melt extraction should result in a complete removal of clinopyroxene from the host rock (Walter 2003). Many points representing the Pilchowice xenoliths are located above the $25 \%$ melt extraction point in the diagram of Upton et al. 2011 (cf. Fig. 11), but they contain from 0.1 to 2.8 vol\% of clinopyroxene, which suggests that the mineral was added to the rock after partial melting event.

The high Cr\# of spinel and its positive correlation with Mg\# (Fig. 9) suggests that the mineral was affected by partial melting. The $\mathrm{Cr} \#$ of spinel can be used to estimate the degree of melt extraction from the host rock (Hellebrand 


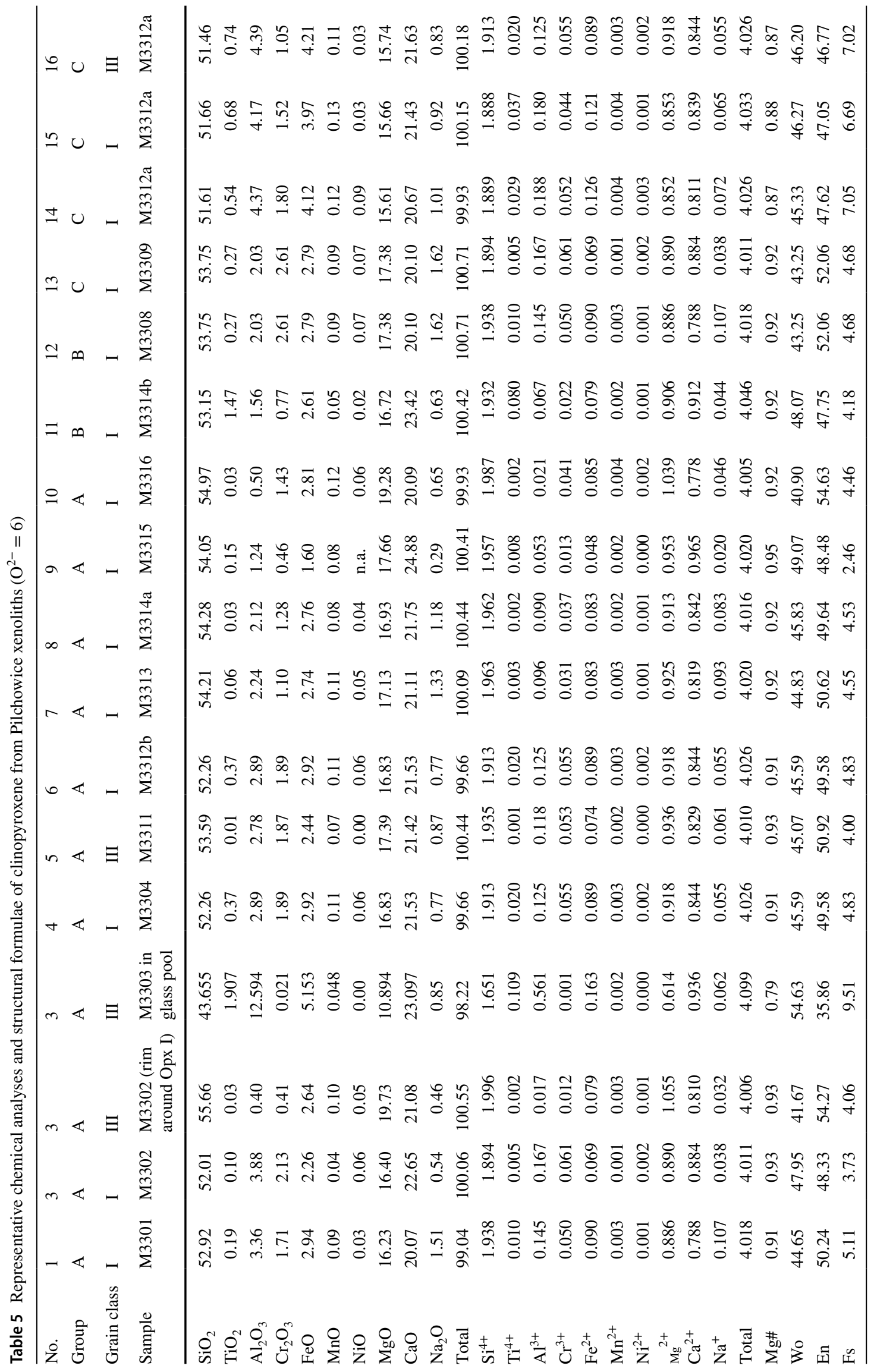


Table 6 Averaged content of trace elements in clinopyroxene from Pilchowice xenoliths (in ppm)

\begin{tabular}{|c|c|c|c|c|c|c|c|c|c|c|}
\hline No. & 1 & 2 & 3 & 4 & 5 & 6 & 8 & 9 & 10 & 11 \\
\hline Group & A & A & A & A & A & A & A & A & A & B \\
\hline Grain class & I & $\mathrm{I}$ & I & I & $\mathrm{I}$ & I & I & I & $\mathrm{I}$ & I \\
\hline Sample & M3301 & M3302 & M3303 & M3304 & M3307 & M3309 & M3312a & M3314a & M3315 & M3314b \\
\hline Number of analyses & 2 & 6 & 3 & 2 & 3 & 9 & 3 & 1 & 5 & 2 \\
\hline $\mathrm{Rb}$ & 0.81 & 0.11 & 0.03 & 20.58 & 4.54 & 7.13 & 2.66 & 1.62 & 0.60 & 7.43 \\
\hline $\mathrm{Ba}$ & 0.24 & 0.02 & 0.09 & 5.18 & 1.29 & 5.00 & 1.18 & 1.71 & 2.40 & 3.55 \\
\hline $\mathrm{Th}$ & 3.40 & 8.64 & 2.14 & 0.90 & 0.76 & 0.58 & 2.38 & 34.89 & 5.15 & 10.39 \\
\hline $\mathrm{U}$ & 2.02 & 11.68 & 2.01 & 0.82 & 0.70 & 0.88 & 0.70 & 34.89 & 19.80 & 0.50 \\
\hline $\mathrm{Nb}$ & 1.04 & 0.46 & 1.31 & 10.68 & 1.32 & 2.99 & 0.76 & 3.05 & 1.87 & 1.06 \\
\hline $\mathrm{Ta}$ & 1.84 & 0.35 & 0.72 & 1.40 & 2.08 & 2.72 & 1.63 & 3.17 & 4.73 & 3.14 \\
\hline $\mathrm{La}$ & 29.33 & 38.69 & 23.43 & 13.04 & 13.21 & 8.86 & 7.96 & 48.46 & 9.71 & 13.60 \\
\hline $\mathrm{Ce}$ & 35.45 & 49.38 & 38.37 & 26.86 & 26.01 & 15.06 & 9.48 & 37.59 & 5.44 & 15.92 \\
\hline $\mathrm{Pb}$ & 0.84 & 3.47 & 1.15 & 1.33 & 0.46 & 1.26 & 1.04 & 6.66 & 2.71 & 1.15 \\
\hline $\operatorname{Pr}$ & 33.19 & 49.49 & 42.15 & 39.25 & 34.02 & 21.65 & 9.79 & 29.06 & 3.37 & 18.66 \\
\hline $\mathrm{Sr}$ & 20.45 & 31.30 & 27.11 & 15.57 & 11.35 & 13.71 & 6.80 & 27.23 & 3.94 & 13.06 \\
\hline $\mathrm{Nd}$ & 30.57 & 41.08 & 42.83 & 49.14 & 38.93 & 25.57 & 10.46 & 24.66 & 2.66 & 21.32 \\
\hline $\mathrm{Zr}$ & 6.43 & 1.38 & 3.83 & 0.32 & 1.42 & 5.13 & 3.81 & 3.84 & 2.30 & 5.94 \\
\hline Hf & 5.32 & 0.41 & 0.71 & 0.18 & 0.64 & 6.28 & 4.20 & 1.14 & 0.98 & 9.01 \\
\hline $\mathrm{Sm}$ & 19.40 & 25.79 & 31.92 & 46.90 & 30.22 & 23.99 & 9.25 & 15.62 & 1.55 & 17.98 \\
\hline $\mathrm{Eu}$ & 15.43 & 20.26 & 26.56 & 40.33 & 27.66 & 19.29 & 8.00 & 12.86 & 1.08 & 16.08 \\
\hline $\mathrm{Ti}$ & 1.15 & 0.04 & 0.08 & 0.28 & 0.63 & 1.90 & 3.23 & 0.09 & 0.54 & 4.61 \\
\hline Gd & 12.11 & 13.62 & 20.09 & 31.31 & 18.84 & 16.45 & 7.24 & 9.69 & 1.05 & 13.22 \\
\hline Dy & 7.12 & 8.50 & 12.12 & 16.14 & 9.57 & 9.90 & 4.71 & 5.67 & 0.98 & 7.98 \\
\hline Ho & 5.33 & 6.73 & 9.00 & 11.58 & 6.64 & 7.73 & 3.66 & 4.28 & 0.97 & 6.18 \\
\hline $\mathrm{Yb}$ & 3.45 & 4.32 & 5.31 & 5.17 & 6.05 & 3.79 & 2.26 & 2.84 & 1.27 & 3.69 \\
\hline $\mathrm{Y}$ & 4.78 & 6.64 & 7.91 & 10.34 & 3.28 & 6.76 & 3.08 & 3.77 & 0.90 & 5.37 \\
\hline $\mathrm{Lu}$ & 2.90 & 3.88 & 4.53 & 3.81 & 2.45 & 3.04 & 1.88 & 2.42 & 1.11 & 2.93 \\
\hline$(\mathrm{La} / \mathrm{Lu})_{N}$ & 10.11 & 9.97 & 5.17 & 3.43 & 5.40 & 2.92 & 4.25 & 19.99 & 8.75 & 4.64 \\
\hline $\mathrm{Ti}^{*}$ & 0.08 & 0.00 & 0.00 & 0.01 & 0.03 & 0.11 & 0.42 & 0.01 & 0.51 & 0.31 \\
\hline $\mathrm{Sr}^{*}$ & 0.64 & 0.69 & 0.64 & 0.35 & 0.31 & 0.58 & 0.67 & 1.01 & 1.31 & 0.65 \\
\hline
\end{tabular}

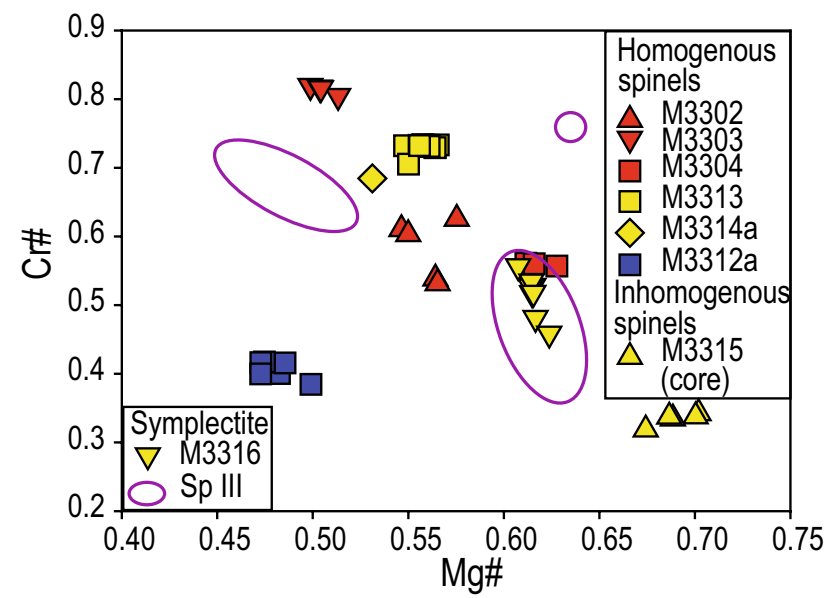

Fig. 9 Cr\# vs Mg\# in spinel from the Pilchowice xenoliths et al. 2001). Our calculations show that degree of melt extraction is similar in all the xenoliths and varies from 19 to $22 \%$ in group $\mathrm{A}$ and $\mathrm{B}$ peridotites. The grains of spinel with the $\mathrm{TiO}_{2}$ content $>0.5 \mathrm{wt} \%$ were not included, as they may be non-residual ones (Pearson et al. 2003).

Major and trace elements contents of clinopyroxene are sensitive to melting and metasomatic events, which affected the mineral. The degree of melt extraction is negatively correlated with the $\mathrm{Al}$ and $\mathrm{Na}$ contents and increases with increasing $\mathrm{Mg \#}$. The Pilchowice clinopyroxene follows a negative $\mathrm{Al}-\mathrm{Na}$ trend, but it deviates from the $\mathrm{MgO}-\mathrm{Al}_{2} \mathrm{O}_{3}$ melting trend proposed by Upton et al. (2011, not showed). This suggests that chemical composition of clinopyroxene might not have been shaped by partial melting but by metasomatic reactions. This is also suggested by the trace element contents, which usually exceed those in primitive mantle (Fig. 8). The exception is xenolith M3315 (subgroup 
Table 7 Representative chemical analyses and chemical formulae of spinels from Pilchowice xenoliths $(K=3)$

\begin{tabular}{|c|c|c|c|c|c|c|c|c|c|}
\hline No. & 1 & 1 & 2 & 2 & 3 & 4 & 5 & 6 & 7 \\
\hline Group & A & A & A & A & A & A & A & B & $\mathrm{C}$ \\
\hline Grain class & I & III & I & III & I & I & I & I & I \\
\hline Sample & M3303 & M3303 & M3304 & M3313 & M3314a & M3315 & M3316 & M3314b & M3312a \\
\hline $\mathrm{SiO}_{2}$ & 0.04 & 0.08 & 0.24 & 0.00 & 0.03 & 0.00 & 0.05 & 0.01 & 0.064 \\
\hline $\mathrm{TiO}_{2}$ & 0.05 & 1.74 & 0.11 & 0.20 & 0.04 & 0.08 & 0.01 & 0.07 & 1.777 \\
\hline $\mathrm{Al}_{2} \mathrm{O}_{3}$ & 8.71 & 16.12 & 23.29 & 13.45 & 15.56 & 37.72 & 28.03 & 23.26 & 28.394 \\
\hline $\mathrm{Cr}_{2} \mathrm{O}_{3}$ & 57.53 & 45.37 & 44.23 & 55.02 & 50.34 & 29.75 & 38.28 & 41.06 & 30.138 \\
\hline $\mathrm{FeO}$ & 20.66 & 22.43 & 16.83 & 17.61 & 19.95 & 13.52 & 16.81 & 20.09 & 25.06 \\
\hline $\mathrm{MnO}$ & 0.24 & 0.27 & 0.16 & 0.23 & 0.21 & 0.09 & 0.15 & 0.18 & 0.197 \\
\hline $\mathrm{NiO}$ & 0.14 & 0.13 & 0.18 & 0.12 & 0.18 & 0.14 & 0.15 & 0.20 & 0.235 \\
\hline $\mathrm{MgO}$ & 11.53 & 11.54 & 15.14 & 12.59 & 12.68 & 17.86 & 15.17 & 14.59 & 13.264 \\
\hline $\mathrm{ZnO}$ & 0.05 & 0.03 & n.a. & 0.11 & 0.09 & 0.25 & 0.13 & n.a. & 0.23 \\
\hline $\mathrm{CaO}$ & 0.00 & 0.05 & 0.08 & 0.00 & 0.04 & 0.01 & 0.02 & 0.01 & 0.003 \\
\hline Total & 98.94 & 97.76 & 100.25 & 99.33 & 99.12 & 99.41 & 98.80 & 99.58 & 99.362 \\
\hline $\mathrm{Si}^{4+}$ & 0.001 & 0.003 & 0.007 & 0.000 & 0.001 & 0.000 & 0.001 & 0.000 & 0.002 \\
\hline $\mathrm{Ti}^{4+}$ & 0.001 & 0.042 & 0.002 & 0.005 & 0.001 & 0.002 & 0.000 & 0.002 & 0.040 \\
\hline $\mathrm{Al}^{3+}$ & 0.340 & 0.615 & 0.826 & 0.509 & 0.584 & 1.254 & 0.987 & 0.832 & 1.004 \\
\hline $\mathrm{Cr}^{3+}$ & 1.505 & 1.162 & 1.052 & 1.398 & 1.267 & 0.663 & 0.904 & 0.986 & 0.715 \\
\hline $\mathrm{Fe}^{3+}$ & 0.150 & 0.130 & 0.100 & 0.281 & 0.150 & 0.090 & 0.110 & 0.180 & 0.210 \\
\hline $\mathrm{Fe}^{2+}$ & 0.420 & 0.470 & 0.320 & 0.250 & 0.380 & 0.230 & 0.310 & 0.330 & 0.420 \\
\hline $\mathrm{Mn}^{2+}$ & 0.007 & 0.007 & 0.004 & 0.006 & 0.006 & 0.002 & 0.004 & 0.005 & 0.005 \\
\hline $\mathrm{Ni}^{2+}$ & 0.004 & 0.003 & 0.004 & 0.003 & 0.005 & 0.003 & 0.004 & 0.005 & 0.006 \\
\hline $\mathrm{Mg}^{2+}$ & 0.569 & 0.557 & 0.679 & 0.603 & 0.602 & 0.751 & 0.676 & 0.660 & 0.594 \\
\hline $\mathrm{Zn}^{2+}$ & 0.001 & 0.001 & 0.000 & 0.003 & 0.002 & 0.005 & 0.003 & 0.000 & 0.005 \\
\hline $\mathrm{Ca}^{2+}$ & 0.000 & 0.002 & 0.003 & 0.000 & 0.001 & 0.000 & 0.001 & 0.000 & 0.000 \\
\hline Total & 2.998 & 2.993 & 2.997 & 3.058 & 2.999 & 3.001 & 3.000 & 3.000 & 3.001 \\
\hline $\mathrm{Cr} \#$ & 0.82 & 0.65 & 0.56 & 0.73 & 0.68 & 0.35 & 0.48 & 0.54 & 0.42 \\
\hline $\mathrm{Mg} \#$ & 0.50 & 0.48 & 0.62 & 0.34 & 0.53 & 0.70 & 0.68 & 0.56 & 0.58 \\
\hline
\end{tabular}

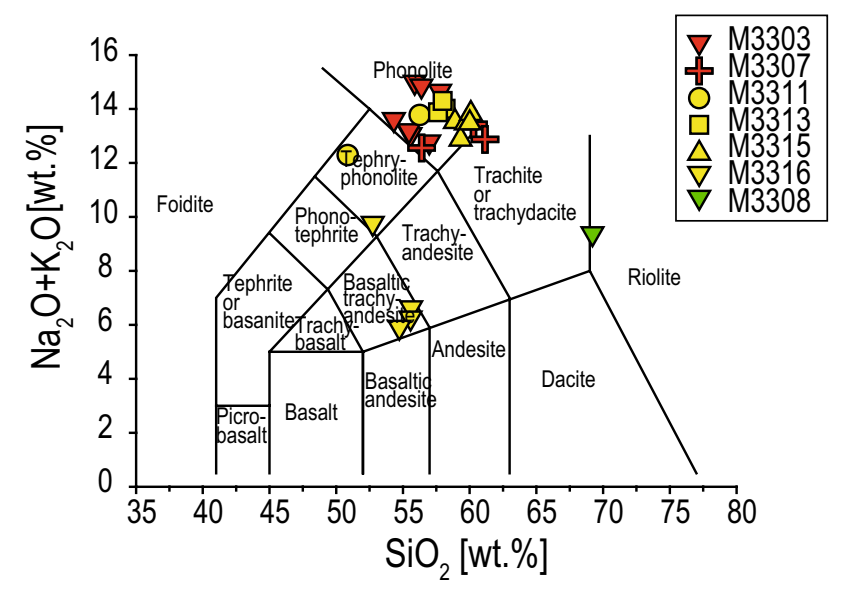

Fig. 10 Total Alkali Silica diagram showing the composition of glasses occurring in intergranular aggregates from the Pilchowice xenoliths
A1) where only the LREE content is elevated and the less incompatible REE (HREE) might have been affected by melt extraction. However, this clinopyroxene is characterized by the very low ( $0.05 \mathrm{apfu}) \mathrm{Al}$ content which would require an unrealistically high degree of melt extraction and, therefore, is possibly not a primary phase.

The discussed data suggest that the group A and B peridotites from Pilchowice are restites after approximately $20-30 \%$ of melt extraction and that the clinopyroxene was added to the rocks after the partial melting event. This scenario seems to be common in off-craton lithospheric mantle (Malarkey et al. 2011; Puziewicz et al. 2015).

\section{Metasomatic events in the Pilchowice peridotites}

The clinopyroxene I occurring in the Pilchowice peridotites was added late in their evolution. Since the mineral was added to clinopyroxene-free rocks, the metasomatic events were of modal nature ("stealth metasomatism", O'Reilly and Griffin 2013). Three kinds of clinopyroxene I occur in the 
Table 8 Chemical composition of glass (1-8) and apatite (9) from Pilchowice xenoliths

\begin{tabular}{|c|c|c|c|c|c|c|c|c|c|}
\hline No. & 1 & 2 & 3 & 4 & 5 & 6 & 7 & 8 & 9 \\
\hline Group & A & A & A & A & A & A & A & B & A \\
\hline Sample & M3303 & M3303 & M3307 & M3311 & M3313 & M3315 & M3316 & M3314b & M3311 \\
\hline $\mathrm{SiO}_{2}$ & 56.97 & 57.78 & 60.29 & 56.26 & 58.19 & 60 & 55.61 & 69.21 & 1.61 \\
\hline $\mathrm{TiO}_{2}$ & 0.8 & 0.68 & 0.22 & n.a. & 0.66 & 0.28 & 0.06 & 0.06 & n.a. \\
\hline $\mathrm{Al}_{2} \mathrm{O}_{3}$ & 22.48 & 25.34 & 20.96 & 20.8 & 27.02 & 22.61 & 27.36 & 15.86 & 0.31 \\
\hline $\mathrm{Cr}_{2} \mathrm{O}_{3}$ & n.a. & n.a. & n.a. & n.a. & n.a. & n.a. & n.a. & 0.08 & n.a. \\
\hline $\mathrm{FeO}$ & 0.77 & 1.1 & 0.38 & 1.04 & 0.55 & 0.52 & 0.38 & 1.15 & 0.18 \\
\hline $\mathrm{MnO}$ & 0.01 & 0.01 & 0.02 & n.a. & n.a. & n.a. & n.a. & 0.03 & n.a. \\
\hline $\mathrm{NiO}$ & n.a. & n.a. & n.a. & n.a. & n.a. & n.a. & n.a. & 0.01 & n.a. \\
\hline $\mathrm{MgO}$ & 0.29 & 0.22 & 0.47 & 0.61 & 0.12 & 0.18 & 0.07 & 1.19 & n.a. \\
\hline $\mathrm{CaO}$ & 0.41 & 0.99 & 0.5 & n.a. & 0.46 & 0.36 & 9.21 & 0.1 & 51.95 \\
\hline $\mathrm{BaO}$ & 0.16 & 0.03 & 0.05 & 2.2 & n.a. & 0.03 & n.a. & n.a. & n.a. \\
\hline $\mathrm{Na}_{2} \mathrm{O}$ & 4.24 & 14.06 & 5.77 & 3.78 & 13.21 & 5.05 & 5.43 & 2.98 & 0.1 \\
\hline $\mathrm{K} 2 \mathrm{O}$ & 8.47 & 0.53 & 7.66 & 10 & 0.8 & 8.51 & 1.13 & 6.33 & n.a. \\
\hline $\mathrm{SrO}$ & n.a. & n.a. & n.a. & n.a. & n.a. & n.a. & n.a. & n.a. & 1.11 \\
\hline $\mathrm{P}_{2} \mathrm{O}_{5}$ & n.a. & n.a. & n.a. & n.a. & n.a. & n.a. & n.a. & n.a. & 39.36 \\
\hline $\mathrm{Cl}$ & n.a. & n.a. & n.a. & n.a. & n.a. & n.a. & n.a. & n.a. & 0.5 \\
\hline $\mathrm{La}_{2} \mathrm{O}_{3}$ & n.a. & n.a. & n.a. & n.a. & n.a. & n.a. & n.a. & n.a. & 0.38 \\
\hline $\mathrm{Ce}_{2} \mathrm{O}_{3}$ & n.a. & n.a. & n.a. & n.a. & n.a. & n.a. & n.a. & n.a. & 0.69 \\
\hline $\mathrm{F}$ & n.a. & n.a. & n.a. & n.a. & n.a. & n.a. & n.a. & n.a. & 3.26 \\
\hline $\mathrm{SO}_{2}$ & n.a. & n.a. & n.a. & n.a. & n.a. & n.a. & n.a. & n.a. & 0.03 \\
\hline Total & 94.6 & 100.74 & 96.34 & 94.69 & 101.02 & 97.6 & 99.25 & 97 & 99.49 \\
\hline $\mathrm{Mg \#}$ & 0.22 & 0.13 & 0.49 & 0.31 & 0.14 & 0.21 & 0.13 & 0.45 & n.d. \\
\hline $\mathrm{Na}_{2} \mathrm{O}+\mathrm{K}_{2} \mathrm{O}$ & 12.71 & 14.59 & 13.43 & 13.77 & 14.01 & 13.56 & 6.56 & 9.31 & n.d. \\
\hline
\end{tabular}

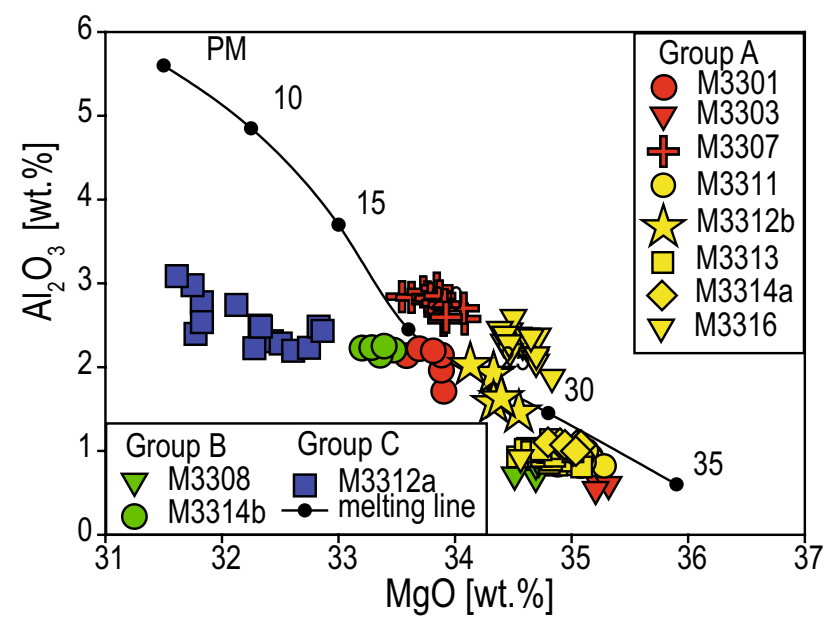

Fig. $11 \mathrm{MgO}$ vs $\mathrm{Al}_{2} \mathrm{O}_{3}$ in orthopyroxene I plot on orthopyroxene's melting trend by Upton et al. (2011). Numbers show degree of melt extraction

Pilchowice group A xenoliths, defining subgroups A1, A2, A3.

Subgroup A1 xenolith M3315 is characterized by the high $\mathrm{Mg \#}$ of clinopyroxene I (0.945-0.955) and the relative low $\mathrm{Mg} \#$ in orthopyroxene I (0.910-0.915). The clinopyroxene is rich in $\mathrm{Ca}$ and poor in $\mathrm{Al}, \mathrm{Na}$ and $\mathrm{Cr}$. Its trace and $\mathrm{REE}$ element patterns show neither features typical of carbonatitic nor silicate melt metasomatism. Similar REE patterns in clinopyroxene have been interpreted by Ionov et al. (2002) as a result of reaction of depleted peridotite with carbonatite-rich melt at distance from a source of melt. Nevertheless, we have calculated the trace element composition of alkaline silicate melt in equilibrium with this clinopyroxene (Fig. 12a). The resulting pattern shows that possible parental melt for group A1 clinopyroxene I was an alkaline silicate melt similar to the host Pilchowice basanite. Metasomatism by silicate melt is suggested also by the high $\mathrm{Ti} / \mathrm{Eu}$ ratio (Fig. 13). High Mg\# in clinopyroxene suggests that its equilibration took place in relatively low temperatures (Brey and Köhler 1990; O'Reilly and Griffin 2013). The time relations between metasomatism and equilibration remain virtually unknown.

The composition of subgroup A2 clinopyroxene is variable in terms of major element composition (Fig. 8). Its REE pattern has a convex-upward shape with the inflection point at Nd (xenoliths M3304 and M3307) or Ce (xenoliths M3301, M3302, M3303). Such inflection is interpreted as a result of the significant difference in clinopyroxene-alkali basaltic melt partition coefficients between LREE and HREE (e.g. Hart and Dunn 1993). Thus, the formation of subgroup 


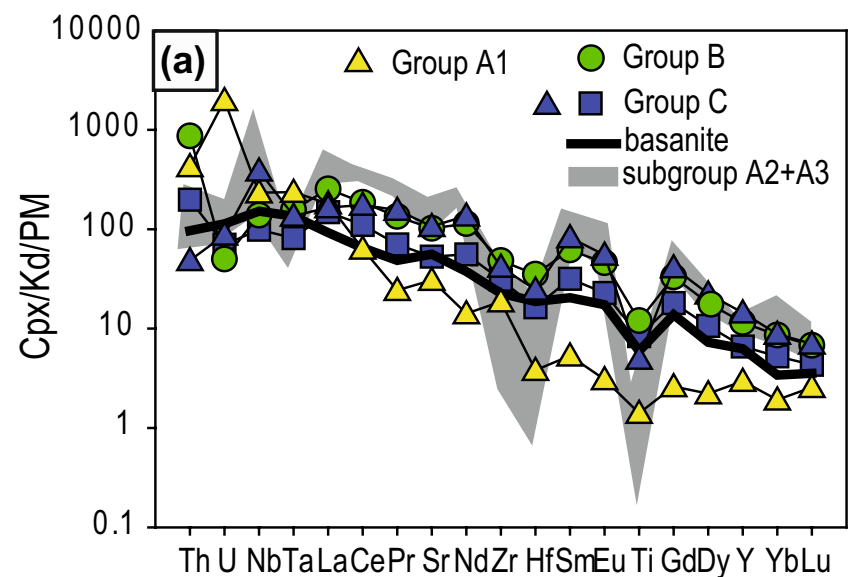

Fig. 12 Calculated trace element composition of alkaline silicate melt (a) and carbonatitic (b) in equilibrium with Pilchowice clinopyroxene I. The composition of calculated melts are compared to composition of host basanite (a, Ntaflos, unpublished data) and carbonatites from

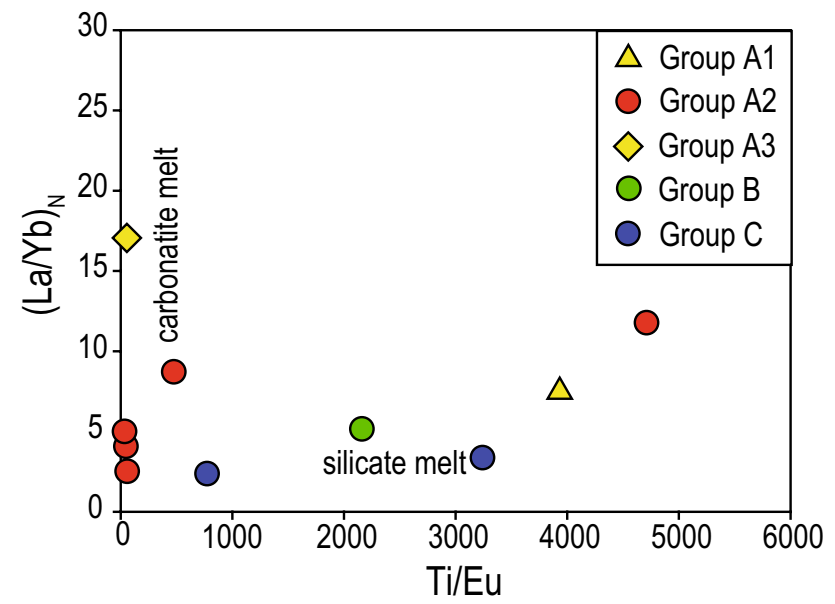

Fig. $13 \mathrm{Ti} / \mathrm{Eu}$ vs. $(\mathrm{La} / \mathrm{Yb})_{N}$ ratios in clinopyroxene I in xenoliths from Pilchowice (diagram after Coltorti et al. 1999)

A2 clinopyroxene was possibly related to reaction with alkaline silicate melt. The trace element composition of melt in equilibrium with subgroup A2 clinopyroxene resembles that of host basanite-normalized patterns of both the melts are parallel except negative $\mathrm{Ti}, \mathrm{Zr}-\mathrm{Hf}$ and $\mathrm{Nb}-\mathrm{Ta}$ anomalies occurring in a hypothetical melt. There is no consensus in the interpretation of $\mathrm{Zr}$, Hf negative anomalies in mantle clinopyroxene (Downes et al. 2015 and references therein). These anomalies can result from (1) melt extraction, or (2) crystallization from carbonatitic melt. Our data show that the clinopyroxene from Pilchowice xenoliths is metasomatic, not restitic; thus, its anomalies are result of carbonatitic melt action. The carbonatite-related origin of clinopyroxene is supported also by its low $(\mathrm{Ti} / \mathrm{Eu})$ and high $(\mathrm{La} / \mathrm{Yb})_{N}$ ratios

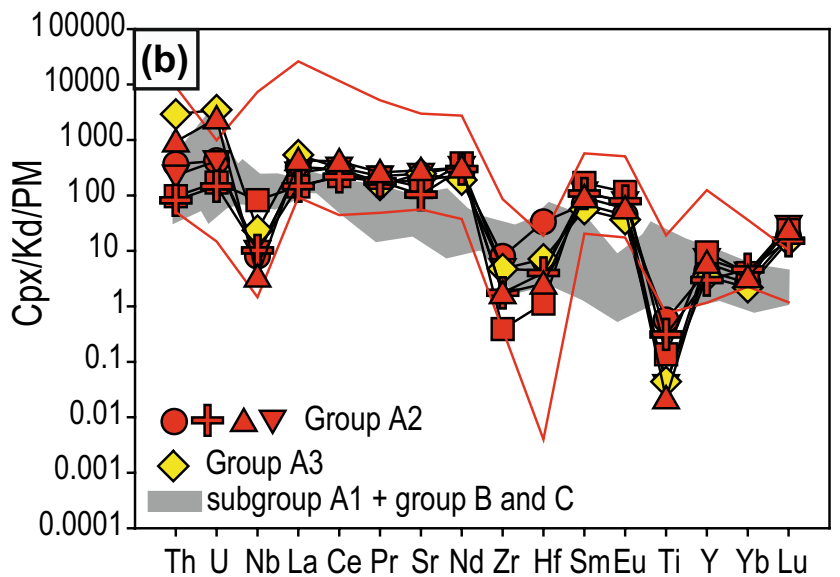

CEVP (b, GEOROC database, Sarbas 2008). Cpx/alkali basalt partition coefficients after Hart and Dunn (1993) and Ionov et al. (2002), those of cpx/carbonatite after Walker et al. (1992), Klemme et al. (1995) and Blundy and Dalton (2000)

(Fig. 13). We have thus compared trace elements composition of carbonatitc melt in equilibrium with Pilchowice clinopyroxene to composition of carbonatite from CEVP (Fig. 12b). A good correlation between the calculated melt and natural carbonatite suggest, that the metasomatic agent was a mixed silicate-carbonatite melt. Supposedly, the A2 xenoliths represent various stages of reaction of harzburgite with the carbonated alkaline silicate melt, which was subjected to unmixing of carbonatite.

Subgroup A3 clinopyroxene I is strongly enriched in LREE and has significant $\mathrm{U}-\mathrm{Th}$ positive and $\mathrm{Ti}, \mathrm{Zr}-\mathrm{Hf}$ and $\mathrm{Nb}-\mathrm{Ta}$ negative anomalies. High contents of $\mathrm{Th}$ and $\mathrm{U}$ with strong depletion in $\mathrm{Ti}$ are considered as indicators of carbonatitic melt (Coltorti et al. 1999). The carbonatite origin of this clinopyroxene is also demonstrated by the lack of inflection in its REE pattern and extremely low Eu/Ti and high $(\mathrm{La} / \mathrm{Yb})_{N}$ ratios (Fig. 13). The calculated hypothetical carbonatite melt equilibrated with $\mathrm{A} 3$ clinopyroxene is very similar to a typical carbonatite composition (Fig. 12b). On the other hand, the xenolith lacks other mineralogical indicators of reaction with carbonatite, like elevated clinopyroxene content, presence of carbonates and/or phlogopite.

Group B is characterized by the lower forsterite content in olivine and $\mathrm{Mg} \#$ in orthopyroxene I. Similar iron-enriched peridotitic xenoliths are widespread at the northern margin of the Bohemian Massif (Puziewicz et al. 2015; MatusiakMałek et al. 2017a, b) and, as they lack cumulative textures, are interpreted as a result of "Fe-metasomatism" of peridotites by alkaline silicate melts.

The trace element of group B clinopyroxene composition is similar to that of clinopyroxene from subgroup A2, but the $\mathrm{Ti}, \mathrm{Zr}-\mathrm{Hf}$ and $\mathrm{Nb}-\mathrm{Ta}$ anomalies in the trace element pattern are significantly less pronounced. We assume, 
by analogy with the group A2, that alkaline silicate melt should be responsible for metasomatism of group B xenoliths. Calculated composition of hypothetical metasomatic melt and low $(\mathrm{La} / \mathrm{Yb})_{N}$ ratio in clinopyroxene supports this view (Figs. 12, 13).

The chemical composition [especially $\mathrm{Mg} /(\mathrm{Mg}+\mathrm{Fe})$ ratios] of phases forming group $\mathrm{C}$ xenoliths are not typical of mantle rocks. Such rocks may result from crystal accumulation from melt migrating through the mantle, and are characterized by: cumulative textures (sometimes recrystallized), high clinopyroxene content and elevated $\mathrm{TiO}_{2}$ content in spinel (Elton and Steward 1992; Borghini and Rampone 2007; Ackerman et al. 2012). Wehrlite M3309 is the only coarse-grained xenolith with texture resembling recrystallized cumulate. To verify its cumulative origin, we have calculated composition of melt in equilibrium with its clinopyroxene I. The trace element composition of the calculated melt strongly resembles that of host basanite (Fig. 12a). Therefore, wehrlite M3309 supposedly originated by crystal settling from a melt similar to the Pilchowice basanite.

Group C xenolith M3312a is a clinopyroxene-bearing dunite with $\mathrm{TiO}_{2}$-rich spinel. The hypothetical melt in equilibrium with that clinopyroxene is similar to the host basanite (Fig. 12a), suggesting the cumulative origin of the rock. However, dunite could also have originated by replacement of orthopyroxene by olivine during percolation of basanitic melt in the surrounding harzburgite (Kelemen et al. 1992). A similar model of dunite origin was proposed for a xenolith suite from the Grodziec locality (Matusiak-Małek et al. 2017b).

Group "C" xenoliths have been described also from other Lower Silesian localities-Grodziec and Wilcza Góra (Matusiak-Małek et al. 2017a, b). Those xenoliths are characterized by cumulative texture and high clinopyroxene content and were interpreted as precipitates from mafic melt.

The relationships between major elements in clinopyroxene from subgroup A2, and groups B and C (Fig. 8) mimic the experimentally produced trend of peridotites reacting with mafic melt (e.g., Tursack and Liang 2012). In those experiments, contents of $\mathrm{Fe}, \mathrm{Ti}$ and $\mathrm{Al}$ in clinopyroxene decrease outwards from the contact between mafic melt and peridotite. In natural occurrences of peridotite (Kelemen 1990; Kelemen et al. 1992; Le Roux et al. 2007), as well as in experiments (Tursack and Liang 2012) peridotite/melt reaction is usually followed by dunitization process which, however, cannot be easily proved in the Pilchowice xenolith suite due to a small size and small number of studied xenoliths.

The data presented in this paper show that clinopyroxene is a late addition to the studied rocks, and thus may not be in chemical equilibrium with orthopyroxene. The relationships between mg-numbers in ortho- and clinopyroxene I in the Pilchowice xenoliths suggest chemical equilibrium as they are similar to the theoretical ones calculated on the basis of the distribution coefficient between these minerals (Tables 3, 5). However, when clinopyroxene-orthopyroxene (Brey and Köhler 1990; Liang et al. 2013) and Al-in-orthopyroxene (Witt-Eickschen and Seck 1991) geothermometers are applied, the resulting temperature differences vary up to $130{ }^{\circ} \mathrm{C}$ within a xenolith. Therefore, in our opinion the calculated temperatures cannot be treated as the reliable ones.

\section{Origin of intergranular aggregates and glassy pools}

The minerals occurring in intergranular aggregates in the Pilchowice xenoliths differ from rock-forming phases (set I) by size and textural position as well as chemical composition. This suggests that origin of the aggregates was different than that of the host rock. Several mechanisms of formation of such aggregates have been proposed in literature: (1) direct infiltration of the host magma (Bonadiman et al. 2011; Shaw and Dingwell 2008); (2) decomposition of hydrous phases (e.g. Aliani et al. 2009; Shaw 2009); (3) melting of peridotite (Carpenter et al. 2002; Shaw et al. 2006) and (4) infiltration ofa meltat mantle depths (Shaw and Klügel 2002);

No hydrous phases (amphibole or phlogopite) occur in the Pilchowice xenoliths thus scenario (2) of formation of aggregates should be excluded. Even, if we assume that amphibole completely broke down to olivine, clinopyroxene, spinel and glass \pm rhönite (Aliani et al. 2009; Shaw 2009; Ladenberger et al. 2006b), the modelled composition of theoretical amphibole does not fit to composition of any of amphibole described in xenoliths from the Lower Silesia area (Matusiak-Małek et al. 2010).

Carpenter et al. (2002) and Shaw et al. (2006) suggested that formation of new clinopyroxene as spongy rims at the cost of the existing one effects from melting of the primary phase. In this scenario, $\mathrm{Al}$ and $\mathrm{Na}$ should decrease in the newly formed phase, whereas $\mathrm{Ca}$ should increase. The $\mathrm{Na}$ and $\mathrm{Ca}$ contents in clinopyroxene III in the Pilchowice xenoliths follow the melting trend, but $\mathrm{Al}$ content is greater compared to that of clinopyroxene I. Refertilization in $\mathrm{Al}$ requires reaction with an alkali silicate melt. This must have happened under pressures exceeding stability limits of plagioclase, because the mineral does not occur in the intergranular aggregates. The lithospheric mantle is located at depth of c. $32 \mathrm{~km}$ in the region (Majdański et al. 2006), thus essentially in the spinel stability field (for detailed discussion see Puziewicz et al. 2011). Therefore, we suppose that the intergranular aggregates were formed due to melt infiltration at mantle depths. The small size of their grains and occurrence of glass indicates crystallization immediately before xenolith were entrained into the erupting lava.

Cores of some of the clinopyroxene III crystals have the same composition as clinopyroxene I while its rims are 
strongly enriched in Al. This suggests that clinopyroxene I was replaced by clinopyroxene III. This view is further supported by a parallel arrangement of clinopyroxene III crystals, which resembles cleavage system and crystallographic axes of clinopyroxene. The composition of both clinopyroxene III grains with and without relics of clinopyroxene I follows the same trends (Fig. 8a, b) and indicates its formation by analogical process.

The only significant chemical difference between olivine I and olivine III is the elevated Ca content in the later. This is best explained by the high calcium activity in the melt from which the olivine crystallized (Jurewicz and Watson 1988).

The composition of glasses occurring in the intergranular aggregates is usually far more evolved than that of the host basanite and reaction with a melt of such composition should strongly decrease the Mg\# in reactive clinopyroxene III, which is not the case (Fig. 8). Moreover, a fine-grained mixture of olivine III, clinopyroxene III and glass enveloping orthopyroxene I is typically interpreted as a result of reaction of the latter with alkaline silicate melt (Shaw et al. 1998). We thus claim, that glasses do not represent the medium which affected clinopyroxene I, but a product of reaction between clinopyroxene I or orthopyroxene I and infiltrating alkaline silicate melt. Products of the reaction depends on the reacting phases (clinopyroxene or orthopyroxene) and may include secondary clinopyroxene, secondary olivine, glass and possibly secondary, $\mathrm{TiO}_{2}$-rich spinel. Therefore, clinopyroxene III may vary in composition depending on weather it was formed due to orthopyroxene I or clinopyroxene I reaction with infiltrating melt.

The angular glass pool in xenolith M3303 contains glass euhedral and acicular subsilicic Al, Fe, Ti diopside ("fassaite") \pm apatite \pm pentlandite \pm chalcopyrite. Their relationships suggest crystallization of acicular clinopyroxene followed by its recrystallization.

\section{Geological significance of the Pilchowice xenoliths}

The xenolith occurrence in Pilchowice is located between the Lubań-Frydlant and Złotoryja-Jawor "volcanic complexes", and is the only xenolith occurrence in the area of radius of ca $25 \mathrm{~km}$. The xenolith suite from Pilchowice shows that the harzburgitic lithospheric mantle (type "A" of Matusiak-Małek et al. 2014) continues from the northernmost termination of the Eger Rift (Steinberg near Görlitz) to the Jawor-Złotoryja "volcanic complex" (Krzeniów near Złotoryja, Matusiak-Małek et al. 2014; see Fig. 1). The chemical compositions of minerals from Pilchowice xenoliths does not differ significantly from those occurring in the region (Fig. 14) on both flanks of ISF. The Intra Sudetic Fault is one of the major Variscan geological boundaries in the region. The reflection seismic study of Żelaźniewicz et al. (1997) shows that the ISF is a shallow NE dipping structure reaching the depths of $12 \mathrm{~km}$. The middle crust located beneath exhibits dome-like structure which is result of a contact between two major Cadomian crustal units (Żelaźniewicz et al. 1997). The underlying mantle is, however, lithologically homogeneous over the distance of at least $70-80 \mathrm{~km}$. This demonstrates the decoupling between crustal and mantle structures within the Lower Silesian part of Saxo-Thuringian domain of Variscan orogen.

\section{Conclusions}

The mantle xenolith suite from Pilchowice is dominated by harzburgites, which experienced significant (20-30\%) melt extraction, which left olivine-orthopyroxene residuum devoid of clinopyroxene. The latter was added in small amounts to the rocks during metasomatic events which occurred subsequently. The metasomatism was induced by mixed carbonatite-silicate melts, which evolution, including possible unmixing of carbonatitic and silicate components, is recorded in variable trace element relationships in clinopyroxene. The droplets of melt resided in the mantle rocks when their pieces were entrained into erupting lava and brought to the surface as xenoliths. The composition of glasses occurring in the solidified melt droplets is variable, showing that alkaline melts percolating lithospheric mantle immediately before the volcanic event were evolving, supposedly due to both reaction with the host and varying physico-chemical conditions.

The mantle section sampled by the Pilchowice basanite at ca $23 \mathrm{Ma}$ is similar to the whole mantle domain beneath Lower Silesia. The latter is essentially harzburgitic and was subjected to extensive melt extraction (Puziewicz et al. 2015). This domain of lithospheric mantle was affected by migrating mixed carbonatite-silicate melts, which induced metasomatic changes of various intensity (e.g. Krzeniów xenolith suite, Matusiak-Małek et al. 2014). Locally (e.g., Księginki, Grodziec) intense effects of alkaline silicate melt percolating in the mantle immediately before the Cenozoic eruptions are recorded in the mantle peridotites (Puziewicz et al. 2011; Matusiak-Małek et al. 2017b).

The Pilchowice basanite occurs at the Intra-Sudetic Fault, which is one of the major tectonic borders in the NE part of Bohemian Massif. The mantle xenolith suite from Pilchowice is, however, similar to other suites from the region, and no significant differences occur in the mantle rocks on the both sides of the Fault (Kukuła et al. 2015; Matusiak-Małek et al. 2014, 2017a, b, 2010; Puziewicz et al. 2011; Ackerman et al. 2007). Our observations support the findings of Żelaźniewicz et al. (1997) that the Intra-Sudetic Fault, albeit a major dislocation in the NE part of the Bohemian massif, is a shallow structure which is not continuing into the middle- and lower crust. The Pilchowice xenolith suite 

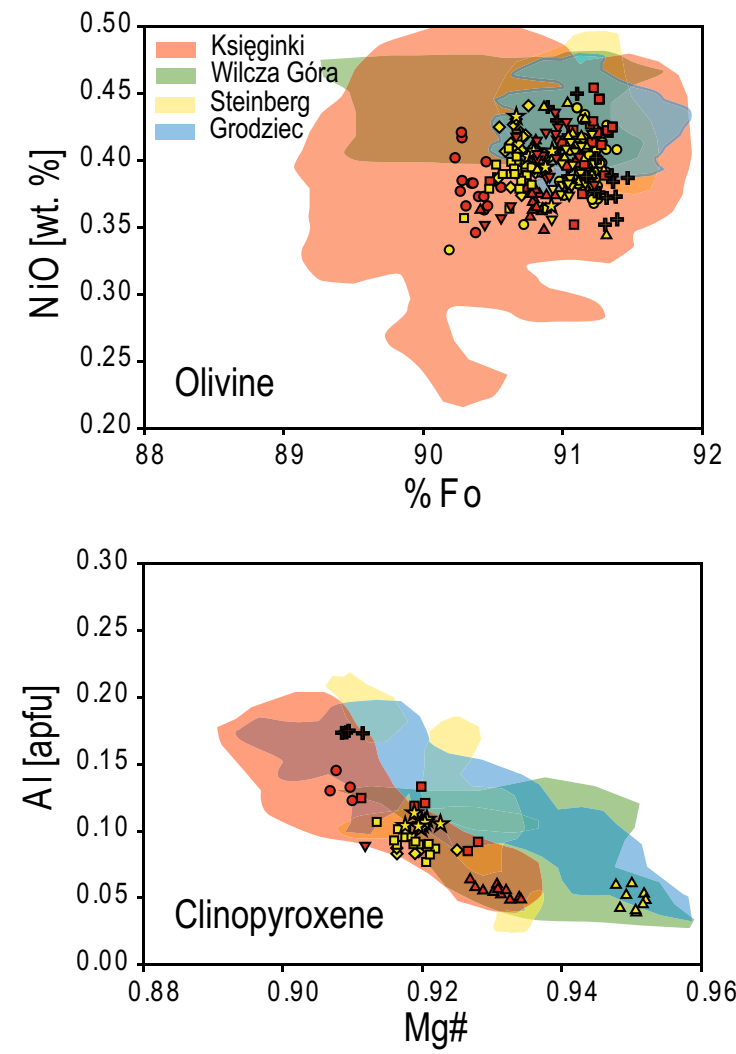

Fig. 14 Chemical parameters of minerals from mantle xenolith suites north and south from ISF. Xenolith localities north from ISF are marked in Fig. 1, data after: Kukuła et al. (2015); Matusiak-Małek et al. (2014, 2017a, b); Puziewicz et al. (2011). One of the xenolith

is isolated from other mantle xenolith occurrences in the region and shows the continuity of Lower Silesian mantle domain in the region.

Acknowledgements This study is partly based on the MSc. thesis of the first author and was funded by National Centre for Scientific Research (DEC-2011/03/B/ST10/06248; funding awarded to M. Matusiak-Małek). We are grateful to Andrzej Żelaźniewicz and Stanisław Mazur for reviews that brought significant improvement of the final version of the paper. We would like to thank M. Dajek and D. Lipa for preparation of maps.

Open Access This article is distributed under the terms of the Creative Commons Attribution 4.0 International License (http://creativecommons.org/licenses/by/4.0/), which permits unrestricted use, distribution, and reproduction in any medium, provided you give appropriate credit to the original author(s) and the source, provide a link to the Creative Commons license, and indicate if changes were made.

\section{References}

Ackerman L, Mahlen N, Jelinek E, Medaris GJ, Ulrych J, Strnad L, Mihaljević M (2007) Geochemistry and evolution of

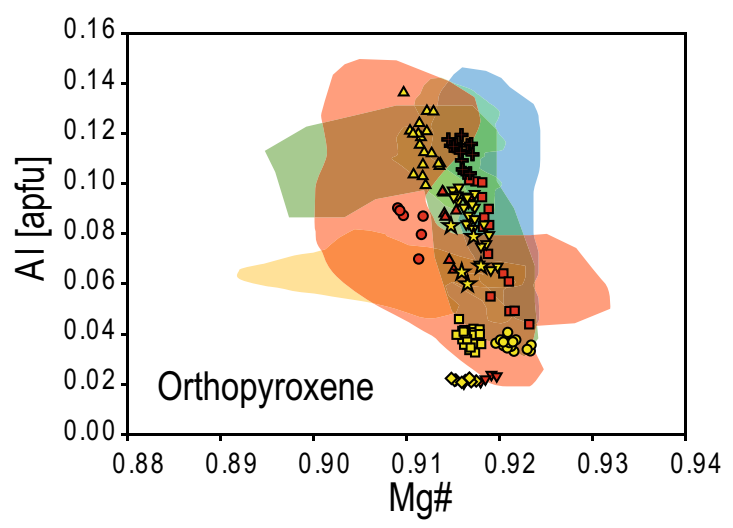

localities south from ISF is marked in Fig. 1, the other one (Kozákov, Czech Republic) is located outside the range of the map; data for xenoliths is after Matusiak-Małek et al. (2010) and Ackerman et al. (2007)

subcontinental lithospheric mantle in central Europe: evidence from peridotite xenoliths of the Kozákov Volcano, Czech Republic. J Petrol 48:2235-2260

Ackermanb L, Špaček P, Medaris G Jr, Hegner E, Svojtka M, Ulrych J (2012) Geochemistry and petrology of pyroxenite xenoliths from Cenozoic alkaline lava, Bohemian Massif. J Geosci 58:199-219

Aleksandrowski P (1994) The Sudetes as a domain of strike-slip tectonics. In: Kryza R (ed) Igneous activity and metamorphic evolution of the Sudetes Area (Magmatyzm i ewolucja metamorficzna regionu sudeckiego), 2nd Conference on Polish-French Cooperation in Geology, Abstracts. Uniwersytet Wrocławski, pp 15-20

Aleksandrowski P, Kryza R, Mazur S, Żaba J (1997) Kinematic data on major Variscan strike-slip faults and shear zones in the Polish Sudetes, Northeast Bohemian Massif. Geol Mag 134:727-739

Aleksandrowski P, Kryza R, Mazur S, Pin C, Zalasiewicz JA (2000) The Polish Sudetes: Caledonian or Variscan ?Trans R Soc Edinb Earth Sci 90(2):127-146

Aliani P, Ntaflos T, Bjerg E (2009) Origin of melt pockets in mantle xenoliths from southern Patagonia, Argentina. J S Am Earth Sci 28:419-428

Arai S (1994) Characterization of spinel peridotites by olivine-spinel compositional relationship: review and interpretation. Chem Geol 113:191-204

Badura J, Przybylski B (2000) Neotectonic map of Lower Silesia. Central Geological Archive, Polish Geological Institute 
Białowolska A (1980) Geochemiczna charakterystyka niektórych bazaltoidów Dolnego Śląska i ich ultramafitowych enklaw. Arch Min 36:107-170

Birkenmajer K, Pécskay Z, Grabowski J, Lorenc MW, Zagożdżon P (2011) Radiometric dating of the Tertiary volcanics in Lower Silesia, Poland. VI. K-Ar and paleomagnetic data from basaltic rocks of the West Sudety mountains and their northern foreland. Ann Soc Geol Pol 81:115-131

Blundy JD, Dalton J (2000) Experimental comparison of trace element partitioning between clinopyroxene and melt in carbonate and silicate systems, and implications for mantle metasomatism. Contrib Mineral Petrol 139(3):356-371

Bonadiman C, Coltorti M, Beccaluva L, Griffin WL, O'Reilly SY, Siena F (2011) Metasomatism versus host magma infiltration: a case study of Sal mantle xenoliths, Cape Verde Archipelago. Geol Soc Am Spec Pap 478:283-305

Borghini G, Rampone E (2007) Postcumulus processes in oceanic-type olivine-rich cumulates: the role of trapped melt crystallization versus melt/rock interaction. Contrib Min Petrol 154:619-633

Brey GP, Köhler T (1990) Geothermobarometry in four-phase lherzolites II. New thermobarometers and practical assessment of existing thermobarometers. J Petrol 31:1353-1378

Carpenter RL, Edgar AD, Thibault Y (2002) Origin of spongy textures in clinopyroxene and spinel from mantle xenoliths, Hessian Depression, Germany. Min Petrol 74:149-162

Coltorti M, Bonadiman C, Hinton RW, Siena F, Upton BGJ (1999) Carbonatite metasomatism of the oceanic upper mantle: evidence from clinopyroxenes and glasses in ultramafic xenoliths of Grande Comore, Indian Ocean. J Petrol 40:133-165

Dèzes P, Schmid SM, Ziegle rPA (2004) Evolution of the European Cenozoic Rift systems: interaction of the Alpine and Pyrenean orogens with their foreland lithosphere. Tectonophysics 389:1-33

DonJ (1984) Kaledonidy i waryscydy Sudetów zachodnich. Przegląd Geol8-9:459-468

Downes H (2001) Formation and modification of the shallow subcontinental lithospheric mantle: a review of geochemical evidence from ultramafic xenolith Suites and tectonically emplaced ultramafic massifs of western and Central Europe. J Petrol 42:233-250

Downes H, deVries C, Wittig N (2015) Zr-Hr anomalies in clinopyroxene from mantle xenoliths from France and Poland: implications for $\mathrm{Lu}-\mathrm{Hf}$ dating of spinel peridotite lithospheric mantle. Int J Earth Sci 104:89-102

Elton D, Steward M (1992) Compositional trends of minerals in oceanic cumulates. J Geophys Res Sol Earth 97(B11):15189-15199

Franke W (2014) Topography of the Variscan orogen in Europe: failed-not collapsed. Int J Earth Sci 103(5):1471-1499

FreyFA, PrinzM (1978) Ultramafic inclusions from San Carlos, Arizona: petrologic and geochemical data bearing on their petrogenesis. Earth Planet Sci Lett38:129-176

Gill R (2010) Igneous Roks and processes. A practical guide. Wiley, Chichester

Griffin WL, O'Reilly SY, Ryan CG (1999) The composition and origin of sub-continental lithospheric mantle. In: FeiY, BertkaCM, MysenBJ (eds) Mantle petrology: field observations and high-pressure experimentations: a tribute to Francis R. (Joe) Boyd. The Geochemical Society Special Publications, Houston, pp 13-45

Hart SR, Dunn T (1993) Experimental cpx/melt partitioning of 24 trace elements. Contrib Min Petrol 113:1-8

Hellebrand E, Snow JE, DickH JB, Hofmann AW (2001) Coupled major and trace elements as indicators of the extent of melting in mid-ocean-ridge peridotites. Nature 410:677-681

Ionov DA, Bodinier JL, Mukasa SB, Zanetti A (2002) Mechanisms and sources of mantle metasomatism: major and trace element compositions of peridotite xenoliths from Spitsbergen in the context of numerical modelling. J Petrol 43:2219-2259

Jochum KP, Weis U, Stoll B, Kuzmin D, Yang Q, Raczek I, Jacob DE, Stracke A, Birbaum K, Frick DA, Günther D, Enzweiler J (2011) Determination of reference values for NIST 610-617 Glasses following ISO Guidelines. Geostand Geoanal Res 35:397-429

Jurewicz AJG, Watson EB (1988) Cations in olivine, Part 2: diffusion in olivine xenocrysts, with applications to petrology and mineral physics. Contr Min Petrol 99:186-201

Kelemen P (1990) Reaction between ultramafic rock and fractionating basaltic magma I. Phase relations, the origin of calc-alkaline magma series, and the formation of doscordant dunite. J Petrol 31:51-98

Kelemen PB, Dick HJB, Quick JE (1992) Formation of harzburgite by pervasive melt/rock reaction in the upper mantle. Nature 358:635-641

Klemme S, van der Laan SR, Foley SF, Günther D (1995) Experimentally determined trace and minor element partitioning between clinopyroxene and carbonatite melt under upper mantle conditions. Earth Planetary Sci Lett 133(3-4):439-448

Kozłowska-Koch M (1987) Klasyfikacja i Nomenklatura Trzeciorzędowych Wulkanitów Dolnego Śląska i Śląska Opolskiego. Arch Min 27:43-95

Kukuła A, Puziewicz J, Matusiak-Małek M, Ntaflos T, Buchner J, Tietz O (2015a) Depleted subcontinental lithospheric mantle and its tholeiitic melt metasomatism beneath NE termination of the Eger Rift (Europe): the case study of the Steinberg (Upper Lusatia, SE Germany) xenoliths. Min Petrol 109:761-787

Kukuła A, Puziewicz J, Ntaflos T (2015b) The origin of the Popiel peridotite (Western Sudetes, SW Poland): metamorphism of the island arc tholeiitic cumulate. Geol Quart 59:239-247

Ladenberger A, Michalik M, Tomek C, Peate DW (2006a) Alkaline magmatism in SW Poland-an example of astenosphere-litosphere interactions?Min Pol Spec Pap 29:40-47

Ladenberger A, Ntaflos T, Michalik M (2006b) Petrogenetic significance of rhönite in basanite from Pilchowice (SW Poland). XII Meeting of the Petrology Group of the Mineralogical Society of Poland. Mineral. Polonica-Spec. Papers, Leśna, Poland, pp 48-51

LeRoux V, Bodinier J-L, Tommasi A, Alard O, Dautria J-M, Vauchez A, Riches AJV (2007) The Lherz spinel lherzolite: refertilized rather than pristine mantle. Earth Planet Sci Lett 259:599-612

Lenoir X, Garrido CJ, Bodinier J-L, Dautria J-M (2000) Contrasting lithospheric mantle domains beneath the Massif Central (France) revealed by geochemistry of peridotite xenoliths. Earth Planet Sci Lett 181:359-375

Liang Y, Sun C, Yao L (2013) A REE-in-two-pyroxene thermometer for mafic and ultramafic rocks. Geochm Cosmochim Acta 102:246-260

Lustrino M, Wilson M (2007) The circum-mediterranean anorogenic Cenozoic igneous province. Earth Sci Rev 81:1-65

Majdański M, Grad M, Guterch A, SUDETES 2003 Working Group (2006) 2-D seismic tomographic and ray tracing modelling of the crustal structure across the Sudetes Mountains basing on SUDETES 2003 experiment data. Tectonophysics 412:249-269

Malarkey J, Wittig N, Graham Pearson D, Davidson J (2011) Characterising modal metasomatic processes in young continental lithospheric mantle: a microsampling isotopic and trace element study on xenoliths from the Middle Atlas Mountains. Moroc Contrib Min Petrol 162:289-302

Matusiak-Małek M, Puziewicz J, Ntaflos T, Grégoire M, Downes H (2010) Metasomatic effects in the litospheric mantle beneath the NE Bohemian Massif: a case study of Lutynia (SW Poland) peridotite xenoliths. Lithos 117:49-60

Matusiak-Małek M, Puziewicz J, Ntaflos T, Gregoire M, Benoit M, Klügel A (2014) Two contrasting lithologies in off-rift 
subcontinental lithospheric mantle beneath Central Europe-the Krzeniów (SW Poland) case study. J Petrol 55:1799-1828

Matusiak-Małek M, Puziewicz J, Ntaflos T, Gregoire M, Kukuła A, Wojtulek PM (2017a) Origin and evolution of rare amphibolebearing mantle peridotites from Wilcza Góra (SW Poland), Central Europe. Lithos 286-287:302-323

Matusiak-Małek M, Ćwiek M, Puziewicz J, Ntaflos T (2017b) Thermal and metasomatic rejuvenation and dunitization in lithospheric mantle beneath Central Europe-The Grodziec (SW Poland) case study. Lithos 276:15-29

Mazur S, Aleksandrowski P, Kryza R, Oberc-Dziedzic T (2006) The Variscan Orogen in Poland. Geol Quart 50(1):89-118

Mazur S, Turniak K, Szczepański J, McNaughton NJ (2015) Vestiges of Saxothuringian crust in the Central Sudetes, Bohemian Massif: zircon evidence of a recycled subducted slab provenance. Gondwana Res 27:825-839

McDonough WF, Sun SS (1995) The composition of the earth. Chem Geol 120:223-253

Mercier JCC, Nicolas A (1975) Textures and fabrics of upper-mantle peridotites as illustrated by xenoliths from basalts. J Petrol $16: 454-487$

Morimoto N (1989) Nomenclature of pyroxenes. Can Mineral $27: 143-156$

Müller W, Shelley M, Miler P, Broude S (2009) Initial performance metrics on a new custom-designed ArF excimer LA-ICPMS system coupled to a two-volume laser-ablation cell. J Anal Atom Spectrom 24:209-214

O’Reilly S, Griffin WL (2013) Mantle metasomatism. Metasomatism and the chemical transformation of rock. Lecture notes in earth system sciences, pp 471-533

OliverG JH, Corfu F, Krogh TE (1993) U-Pb ages from SW Poland: evidence for a Cadomian suture zone between Baltica and Gondwana. J Geol Soc 150:355-369

Pearson DG, Canil D, Shirey SB, Heinrich DH, Karl KT (2003) Mantle samples included in volcanic rocks: xenoliths and diamonds. Treatise on Geochemistry. Pergamon, Oxford, pp 171-275

Plomerová J, Babuška V (2010) Long memory of mantle lithosphere fabric-European LAB constrained from seismic anisotropy. Lithos 120:131-143

Puziewicz J, Koepke J, Grégoire M, Ntaflos T, Matusiak-Małek M (2011) Lithospheric mantle modification during cenozoic rifting in Central Europe: evidence from the Księginki Nephelinite (SW Poland) Xenolith Suite. J Petrol 53:2107-2145

Puziewicz J, Matusiak-Małek M, Ntaflos T, Grégoire M, Kukuła A (2015) Subcontinental lithospheric mantle beneath Central Europe. Int J Earth Sci 104:1913-1924

Shaw CSJ (2009) Textural development of amphibole during breakdown reactions in a synthetic peridotite. Lithos 110:215-228

Shaw CSJ, Dingwell DB (2008) Experimental peridotite-melt reaction at one atmosphere: a textural and chemical study. Contrib Min Petrol 155:199-214
Shaw CSJ, Klügel A (2002) The pressure and temperature conditions and timing of glass formation in mantle-derived xenoliths from Baarley, West Eifel, Germany: the case for amphibole breakdown, lava infiltration and mineral-melt reaction. Min Petrol 74:163-187

Shaw CSJ, Thibault Y, Edgar AD, Lloyd FE (1998) Mechanisms of orthopyroxene dissolution in silica-undersaturated melts at 1 atmosphere and implications for the origin of silica-rich glass in mantle xenoliths. Contrib Mineral Petrol 132(4):354-370

Shaw SJ, Heidelbach F, Dingwell DB (2006) The origin of reaction textures in mantle peridotite xenoliths from Sal Island, Cape Verde: the case for "metasomatism" by the host lava. Contrib Min Petrol 151:681-697

Szałamacha J (1974) Detailed geological map of the Sudetes in scale 1: 25000. Sheet Siedlęcin, Warszawa, Polish Geological Institute

Tursack E, Liang Y (2012) A comparative study of melt-rock reactions in the mantle: laboratory dissolution experiments and geological field observations. Contrib Min Petrol 163:861-876

Upton BGJ, Downes H, Kirstein LA, Bonadiman C, Hill PG, Ntaflos $\mathrm{T}$ (2011) The lithospheric mantle and lower crust-mantle relationships under Scotland: a xenolithic perspective. J Geol Soc 168:873-886

vanAchterberg E, Ryan CG, Jackson SE, Griffin WL (2001) Data reduction software for LA-ICP-MS. In: SylvesterPJ (ed) Laser-ablation-ICPMS in the earth sciences: principles and applications. Mineralogical Association of Canada, Canada, pp 239-243

Walker D, Beattie P, Jones JH (1992) Partitioning of U-Th-Pb and other incompatibles between augite and carbonate liquid at $1200 \mathrm{C}$ and 55 kbar. Trans Am Geophys Union 73:616

Walte rMJ (2003) Melt extraction and compositional variability in mantle lithosphere. Treatise on Geochemistry. Pergamon, Oxford, pp 363-394

Wilson M, Downes H (2006) Tertiary-quaternary intra-plate magmatism in Europe and its relationship to mantle dynamics "European Lithosphere Dynamics" Memoir. Geological Society, London, pp 147-166

Wimmenauer W (1974) The alkaline province of Central Europe and France. In: SørensenH (ed) The alkaline rocks. Wiley, London, pp 286-291

Witt-Eickschen G, Seck HA (1991) Solubility of Ca and Al in orthopyroxene from spinel peridotite: an improved version of an empirical geothermometer. Contrib Min Petrol 106:431-439

Żelaźniewicz A, Franke W (1994) Discussion on U-Pb ages from SW Poland: evidence for a Caledonian suture zone between Baltica and Gondwana. J Geol Soc London 151:1049-1055

Żelaźniewicz A, Cwojdziński S, England RW, Zientara P (1997) Variscides in the Sudetes and the reworked Cadomian orogen: evidence from the GB-2A seismic reflection profiling in southwestern Poland. Geol Quart 41:289-308 